\title{
Bio-energy in Europe: changing technology choices
}

\author{
André P.C. Faaij* \\ Department of Science, Technology and Society, Copernicus Institute for Sustainable Development \& Innovation, Utrecht University, \\ Heidelberglaan 2, 3584 CS Utrecht, The Netherlands
}

Available online 7 December 2004

\begin{abstract}
Bio-energy is seen as one of the key options to mitigate greenhouse gas emissions and substitute fossil fuels. This is certainly evident in Europe, where a kaleidoscope of activities and programs was and is executed for developing and stimulating bio-energy.

Over the past 10-15 years in the European Union, heat and electricity production from biomass increased with some $2 \%$ and $9 \%$ per year, respectively, between 1990 and 2000 and biofuel production increased about eight-fold in the same period. Biomass contributed some two-thirds of the total renewable energy production in the European Union (EU) (2000 PJ) or 4\% of the total energy supply in 1999. Given the targets for heat, power and biofuels, this contribution may rise to some $10 \%$ (6000 PJ) in 2010 .

Over time, the scale at which bio-energy is being used has increased considerably. This is true for electricity and combined heat and power plants, and how biomass markets are developing from purely regional to international markets, with increasing crossborder trade-flows. So far, national policy programs proved to be of vital importance for the success of the development of bioenergy, which led to very specific technological choices in various countries. For the future, a supra-national approach is desired: comprehensive research development, demonstration \& deployment trajectories for key options as biomass integrated gasification/ combined cycle and advanced biofuel concepts, develop an international biomass market allowing for international trade and an integral policy approach for bio-energy incorporating energy, agricultural, forestry, waste and industrial policies. The Common Agricultural Policy of the (extended) EU should fully incorporate bio-energy and perennial crops in particular.
\end{abstract}

(C) 2004 Elsevier Ltd. All rights reserved.

Keywords: European bio-energy policy; Biomass resources; Biofuels

Abbreviations: (A/P)CFB, (atmospheric/pressurized) circulating fluidized bed; BFB, bubbling fluidized bed; $\mathrm{BIG} / \mathrm{CC}$, biomass integrated gasification/combined cycle; CAP, Common Agricultural Policy; CEEC, central and eastern European countries; CHP, combined heat and power; DG-TREN, Directorate General-Transport and Energy; DG-RTD, Directorate General-Research and Technology Development; EC, European Commission; EJ, ExaJoule; EU, European Union; FT, Fischer-Tropsch; GEF, global environment facility; GJ, GigaJoule $\left(10^{9} \mathrm{~J}\right)$; GHGs, greenhouse gasses; HTU, hydro thermal upgrading; LHV, lower heating value; MDF, medium density fiber board; MSW, municipal solid waste; $\mathrm{MW}_{\mathrm{th}}$, MegaWatt thermal capacity; PJ, PetaJoule $\left(10^{15} \mathrm{~J}\right)$; RDD\&D, research development, demonstration \& deployment; RDF, refuse-derived fuel; RET, renewable energy technology; RME, rapeseed methyl ester; SRC, short-rotation coppice; odt, oven dry tonne

${ }^{*}$ Tel.: + 31-30-2537643; fax: + 31-30-2537601.

E-mail address: a.faaij@chem.uu.nl (A.P.C. Faaij).

\section{Introduction}

Bio-energy is already seen as one of the key options on shorter and medium term to mitigate greenhouse gas (GHG) emissions and substitute fossil fuels. This is certainly evident in Europe, where a kaleidoscope of activities and programs is executed for developing and stimulating bio-energy, both on the European (European Commission-EC) and national level. Basically every country in Europe has included bio-energy in its energy and climate policies. In addition, production of biomass crops or use of available resources is often linked to agricultural policy. For the European Union (EU), targets have been set for bio-energy: in 2010 almost $10 \%$ of the energy supply of the EU is to come from biomass (Commission of the European Communities, 1997). A country like Sweden formulated that 
$40 \%$ of its primary energy supply should be covered by biomass around 2020 (NUTEK, 1996). Another example is a recent EC-directive on biofuels for the transport sector, which has set targets for the use of biomass for transport fuels (Commission of the European Communities, 2001a-d). Such targets are in line with various global scenario studies for bio-energy which indicate that biomass may contribute 100 to over $400 \mathrm{EJ}$ (or $25 \%$ to almost $100 \%$ of the current world's energy use) to the world's energy supply during this century (Hoogwijk et al., 2003; Ishitani and Johansson, 1996; IIASA/WEC, 1998; Shell, 1995).

Bio-energy is quite an a typical energy supply option due to its diversity and inter-linkages with many other technological (thermo-chemical conversion options, biotechnology, agronomic, etc.) and policy areas (climate, energy, agriculture and waste policy). Also, the availability and use of biomass are intertwined with various major sectors of the economy: agriculture, forestry, food processing, paper and pulp, building materials and, of course, the energy sector in the widest sense. Seen from the positive side, this gives bio-energy many opportunities to generate multiple benefits apart from energy generation. On the other hand, the implementation of bio-energy systems can also conflict with many interests and often projects are very complex especially due to all those inter-linkages. Realization of bio-energy projects often proves difficult. Fuel availability over time, alternative applications, varying prices and sources of income are some general difficulties. A current observation is also that many different bioenergy options are deployed and, despite trends that will be discussed in this paper, probably no clear winners have emerged so far.

It seems little work has been published in the scientific literature covering overviews on the development of bioenergy, the portfolio of options and related policies over time. Most publications on the topic focus on individual countries or specific technological options (see, e.g. Hillring, 2002; Kwant, 2003; Kaltschmitt et al., 1998) and say little about generic trends in the field.

Therefore, the objective of this paper is to provide an overview of the development of commercial, modern bio-energy use in the EU over the past 10-15 years and more in particular how various options and technologies for producing bio-energy developed over time, with what objectives and how such developments were supported via various national and EU programs and activities. As a result, some generic conclusions are to be drawn on bio-energy policies in the future given the ambitions for this option on shorter and longer term.

Section 2 discusses the various key technological options in some detail, distinguishing between different biomass resources (waste streams, residues from forestry and agriculture and specially cultivated crops for energy production such as rapeseed and perennial crops as
Willow and Miscanthus). Subsequently, the main technologies (production of heat, power and fuels for the transport sector) are reviewed. Both the performance levels and their technological status over time will be discussed. Focus will be on the European (EU) context.

In Section 3, a brief overview will be given on policy on bio-energy in Europe. A distinction is made between the developments on the European level, largely driven by the EC and the European research programs, on the one hand, and the variety of national programs of the EU member states, on the other hand.

Finally, Section 4 will give an outlook for bio-energy in Europe based on various policy objectives and information on the potential and technological possibilities that exist for bio-energy in Europe, finalized with a discussion on the main trends and lessons learned for development of bio-energy over time.

For this paper information mostly from the open literature was used. Besides review studies on technological options and biomass resource potentials, various scenario studies and policy documents both from the EC and country information was compiled. Furthermore, expert views played a role in the review.

\section{Key options for bio-energy production}

This section consists of three main parts: Section 2.1 describes the characteristics and potentials of biomass resources, Section 2.2 covers the status and performance of current and future technologies for heat and power generation. Section 2.3 does the same for production of transport fuels from biomass.

\subsection{Resources: biomass residues and organic wastes}

Biomass resources that can be used for energy are diverse. A distinction can be made between primary, secondary and tertiary residues (and wastes), which are available already as a by-product of other activities and biomass that is specifically cultivated for energy purposes (Hoogwijk et al., 2003):

- Primary residues are produced during production of food crops and forest products, e.g. thinnings from commercial forestry and straw. Such biomass streams are typically available 'in the field' and need to be collected to be available for further use.

- Secondary residues are produced during processing of biomass for production of food products or biomass materials, and are typically available in the food and beverage industry, saw and paper mills, etc.

- Tertiary residues become available after a biomassderived commodity has been used, meaning a diversity of waste streams is part of this category, varying from the organic fraction of municipal 
solid waste (MSW), waste and demolition wood, sludges, etc.

In general, biomass residues (and wastes) are intertwined with a complex of markets. Many residues have useful applications such as fodder, fertilizer and soil conditioner, raw material for, e.g., particle board, medium density fiber board (MDF), recycled paper, etc. Net availability as well as (market) prices of biomass residues and wastes therefore generally depend on market demand, local as well as international markets for various raw materials and on the type of waste treatment technology deployed for remaining material. The latter is particularly relevant when tipping fees apply, giving some organic waste streams a (theoretical) negative value.

Typically, the net availability of organic wastes and residues can fluctuate and is influenced by market developments, and also by climate (high- and lowproduction years in agriculture) and other factors.

The physical and chemical characteristics of this diverse spectrum of biomass resources also vary widely. Various streams such as sludges, residues from food processing and several wastes are very wet, with moisture content over 60-70\%. Other streams are more or less contaminated with heavy metals (some waste wood) or have higher chlorine, sulfur or nitrogen contents, depending on the origin, part of the original crop a.o. (for an overview of biomass characteristics see, Faaij et al., 1997a,b). It is therefore difficult, if not impossible, to make clear distinctions between "clean" and "dirty" biomass resources. Clearly, the different properties of biomass resources lead to varying suitability to be converted by different conversion technologies. This aspect will be addressed again in Section 2.2.

Energy cropping: In addition to utilization of wastes and residues, biomass can be produced through dedicated production of crops for energy production, sometimes called 'energy farming', with a variety of crops. Some agricultural (annual) crops such as rapeseed and cereals are presently cultivated for energy purposes in Europe. Both crops are intermixed with conventional agricultural production and find an application for production of transport fuels. Perennial crops are planted for a longer period of time (e.g. 15-20 years) and harvest can take place at regular intervals. Willow is a good example of a short-rotation coppice (SRC) crop that is harvested every $2-5$ years over a period of some 20-25 years. Most experience with SRC-Willow systems is gained in Sweden where this crop is produced on some 14,000 ha (Hillring, 2002). Poplar and grasses like Miscanthus (which are harvested each year) and Sweet Sorghum are also examples of perennial crops, which gained interest in the European context. Commercial use for energy production is, however, negligible at present.
In general, dedicated biomass production is more expensive per unit of energy produced than the use of available residues and wastes. Typical cost ranges for perennial woody crops under North Western European conditions are 3-6€/GJ (compared to some $1-2 € / G J$ for imported coal). Biomass production costs of dedicated production systems are especially dependent on the costs of land and labor and the (average) yield per hectare. Typically, land costs (e.g. through land rent) can contribute about one-third of the total biomass production costs under NW European conditions (van den Broek, 2000). Both land and labor are relatively expensive production factors in Europe, which are indirectly maintained due to the structural agricultural subsidies, which are in turn part of the Common Agricultural Policy (CAP) of the EU. In addition, agricultural surpluses in the EU are (partially) counteracted by measures to take agricultural land out of production (fallow land). This land category could in theory be available for energy crop production, but the total fallow land surface varies over the years (varying from $10 \%$ to less than $3 \%$ of the arable land over the years) and is generally taken up in typical rotation systems of farmers, making introduction of perennial crops difficult. This is also a partial explanation for the relative popularity of annual crops for energy purposes (such as rapeseed and interest for hemp).

A somewhat older study analyzing the potential for renewable energy technologies (RETs) in the EU-15 is the so-called TERES study. With the help of four scenarios the RET penetration in 2020 is estimated. TERES distinguished between seven categories relevant for bio-energy: landfill gas, MSW, industrial waste (here summarized as: wastes), biofuels and wood (here summarized as crops, although the category biofuels implies secondary energy carriers and not a primary fuel), agricultural waste and forest residues (here summarized as biomass residues). A more detailed overview is given in Fig. 1. Summarizing, the ranges between the most optimistic and pessimistic scenarios project the following contributions for bio-energy in the EU-15 in 2020 (TERES, 1997):

$\begin{array}{ll}\text { Wastes } & 1600-2300 \mathrm{PJ} \\ \text { Crops } & 500-3000 \mathrm{PJ} \\ \text { Residues } & 1300-1500 \mathrm{PJ} \text { (the bulk being forest } \\ & \text { residues) }\end{array}$

Total 3400-6800 PJ (projected energy use EU-15: 68,000 PJ)

In Europe, organic wastes (in particular MSW) and forest residues represent the largest available potential and deliver the largest contribution to energy production from organic (renewable) material. As indicated above, market developments, natural fluctuations as well as the economics and various other factors (such as 


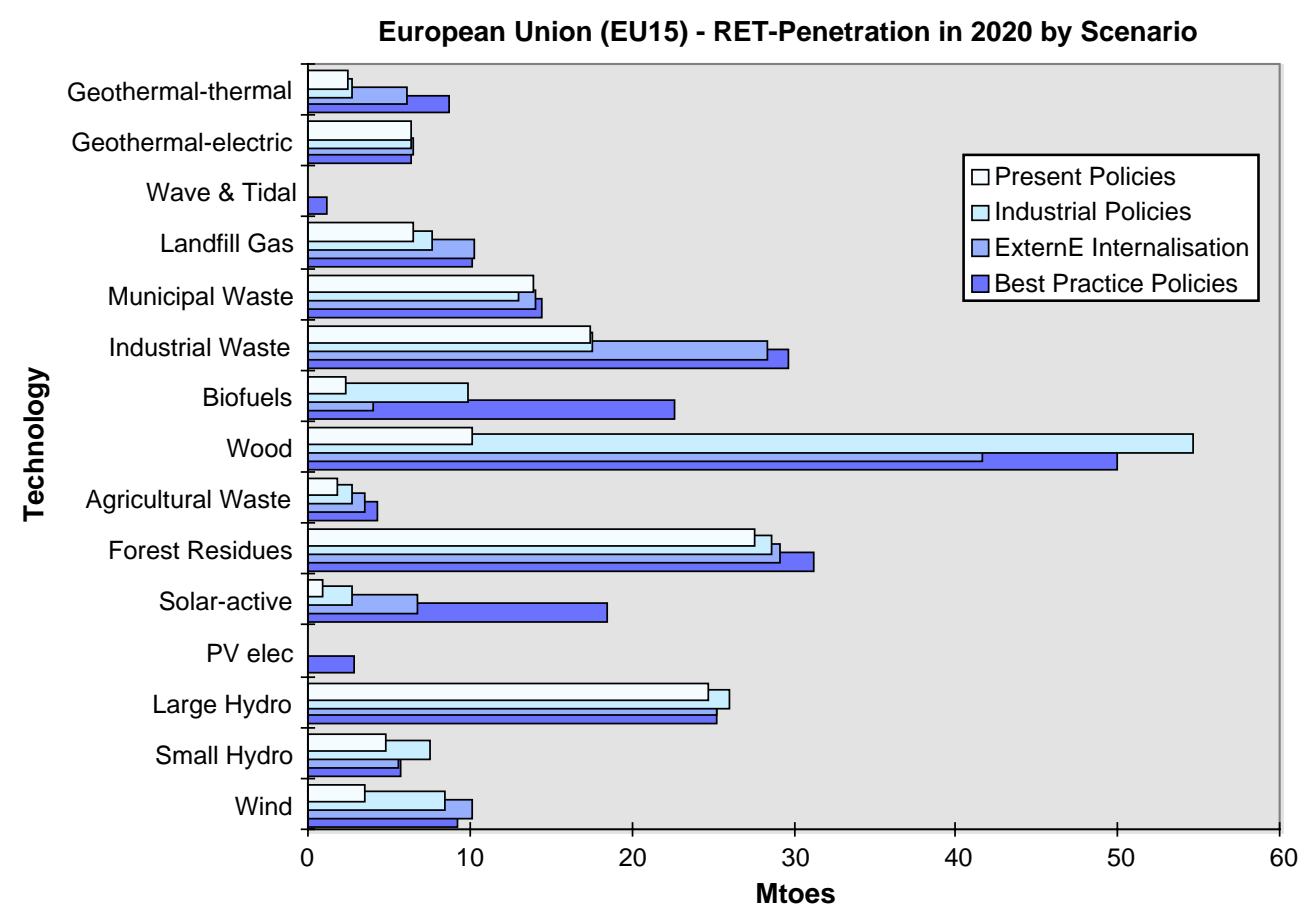

Fig. 1. Overview of the contribution of various renewables to the energy supply of the EU-15 in 2020 according to four different scenarios (taken from the TERESII study, TERES, 1997).

accessibility) of bio-energy all influence the technical and economic potential of such resources and it is impossible to give exact estimates of the potential.

Land use in the EU for agriculture, forest and other purposes is strongly influenced by (agricultural) policy and various subsidies. The real potential for energy crops in the EU is therefore also strongly dependent on such policies. By the end of the nineties, the EC allowed the use of fallow land subsidies for production of nonfood crops, which proved a stimulus for production of energy crops. However, the time period for doing so was limited to 5 years, which is generally not sufficient for a perennial cropping system with a lifetime of some 20 years. Recent developments point to lowering subsidy levels in agriculture and using remaining subsidies for different targets rather than supporting agricultural output, examples being maintenance of landscape and nature and environmental protection.

The potential range of land surface possibly available for energy cropping in the EU is not studied in a great amount of detail, although some scenario analyses exist. An older study from 1992 (WRR, 1992) estimated the potential surplus agricultural land in the EU-12 (so excluding frontrunner countries like Sweden and Finland) in a 20-25-year-time period might be 50-100 million hectares. Assuming an annual yield of 12 odt/ hayr $(18 \mathrm{GJ} /$ odt $)$ this would result in an energy production of $11,000-22,000 \mathrm{EJ} / \mathrm{yr}$, approximately $20-40 \%$ of the total primary energy use of the EU-12 at the time (Faaij et al., 1997a, b). The possibilities for an extended EU (EU-25 or EU-27) including countries as Poland, Rumania and possibly the Ukraine, could be far larger, especially because the productivity of agriculture in Eastern Europe is far lower than in the present EU, thus leaving ample room for increasing productivity and thus maintaining agricultural output on a smaller surface of land. Considering the current costs for land and labor in Eastern Europe (as well as the large surfaces of high-quality agricultural land) energy crop production could result in attractive cost levels (e.g. well below $2 € / G J$ ), which is a cost level that makes large-scale use of biomass at competitive cost levels possible (see also Section 2.2 and Table 3). Table 1 summarizes some main characteristics and the current status of a selection of (potential) energy crops in Europe.

Over time (i.e. starting in the eighties) several stages may be observed in biomass utilization and market developments in biomass supplies. Different countries seem to follow these stages over time, but clearly differ in the stage of development (see also Table 4, which briefly summarizes the bio-energy policies and use in various EU countries):

1. Waste treatment (e.g. MSW and use of process residues (paper industry, food industry) 'on site' of production facilities is generally the starting phase of a developing bio-energy system. Resources are available and often have a negative value, making 
Table 1

Performance characteristics of some (potential) energy crops considered on short and long term in Europe and current status (sources used include: Broek, 2000; Biewinga and van der Bijl, 1996; Dornburg et al., 2003; Borjesson, 1999; Hall et al., 1993)

\begin{tabular}{|c|c|c|c|c|c|c|}
\hline Crop & & $\begin{array}{l}\text { Typical yield } \\
\text { ranges (odt/ha yr) }\end{array}$ & $\begin{array}{l}\text { Energy inputs } \\
\left(G J_{\text {prim }} / \text { ha yr }\right)\end{array}$ & $\begin{array}{l}\text { Typical net } \\
\text { energy yield } \\
(\mathrm{GJ} / \text { ha yr) }\end{array}$ & $\begin{array}{l}\text { Production cost } \\
\text { ranges European } \\
\text { context }(€ / G J)\end{array}$ & Status in Europe and other remarks \\
\hline \multirow[t]{2}{*}{ Rape } & Short term & $\begin{array}{l}2.9 \text { (rapeseed), } 2.6 \\
\text { (straw) }\end{array}$ & 11 & 110 (total) & 20 & \multirow{4}{*}{$\begin{array}{l}\text { Widely deployed in Germany and France, to } \\
\text { lesser extent in Austria and Italy. Requires } \\
\text { better quality land. Annual crop fitting } \\
\text { rotation schemes. Depends on considerable } \\
\text { subsidies to compete, also on longer term. } \\
\text { Annual crop requires good-quality land. } \\
\text { High productivity and also higher emission } \\
\text { levels of agrichemicals. Deployment in } \\
\text { Europe for energy production is (only } \\
\text { surpluses are used for ethanol). }\end{array}$} \\
\hline & Longer term & $\begin{array}{l}4 \text { (rapeseed), } 4.5 \\
\text { (straw) }\end{array}$ & 12 & 180 (total) & 12 & \\
\hline \multirow[t]{2}{*}{ Sugar beet } & Short term & 14 & 13 & 250 & 12 & \\
\hline & Longer term & 20 & 10 & 370 & 8 & \\
\hline \multirow[t]{2}{*}{ SRC-Willow } & Shorter term & 10 & 5 & 180 & $3-6$ & Perennial crop with typical rotation of some \\
\hline & Longer term & 15 & 5 & 280 & $<2$ & $\begin{array}{l}\text { 3-4 years. Suited for colder and wetter } \\
\text { climates. Commercial experience gained in } \\
\text { Sweden and to a lesser extent in the UK and } \\
\text { some other countries. Major interest from } \\
\text { Eastern Europe, where conditions are well } \\
\text { suited. On a somewhat longer term in CEEC } \\
\text { low cost levels can be achieved. }\end{array}$ \\
\hline \multirow[t]{2}{*}{ Poplar } & Shorter term & 9 & 4 & 150 & $3-4$ & Perennial crop, currently especially planted \\
\hline & Longer term & 13 & 4 & 250 & $<2$ & $\begin{array}{l}\text { for pulpwood production in various } \\
\text { countries. Current typical rotation times } \\
8-10 \text { years. Poplar is well suited to deliver } \\
\text { both biomaterial and energy fractions as a } \\
\text { typical multi-product system. Economy } \\
\text { depends on production region as well as } \\
\text { market prices for main material produced. }\end{array}$ \\
\hline \multirow[t]{2}{*}{ Miscanthus } & Shorter term & 10 & $13-14$ & 180 & $3-6$ & Perennial C4-crop that is harvested each \\
\hline & Longer term & 20 & $13-14$ & 350 & $\sim 2$ & $\begin{array}{l}\text { year. So far, only limited commercial } \\
\text { experience in Europe. Breeding potential } \\
\text { hardly explored. Suited for warmer climates, } \\
\text { where principally high yields are possible. }\end{array}$ \\
\hline
\end{tabular}

Note: Biomass logistics: for woody crops, transport, handling and storage costs add about $10 \%$ to the fuel costs in case of road transport in the vicinity of the plant. Energy inputs are about $1-2 \%$ of the heating value of the biomass (somewhat higher for sugar beet). When long-distance transport (intercontinental) transport is considered, the logistics can add between 0.5 and $1 € /$ GJ. Energy inputs can vary between $6 \%$ and $10 \%$ of the heating value of the biomass.

HHV per dry tonne is used for calculating energy yields: wood, $19 \mathrm{GJ} /$ tonne; rapeseed, $28 \mathrm{GJ} /$ tonne; straw, $16 \mathrm{GJ} /$ tonne; sugar beet, $19 \mathrm{GJ} /$ tonne.

utilization profitable and simultaneously solving waste management problems.

2. Local utilization of resources from forest management and agriculture. Such resources are more expensive to collect and transport, but usually still economically attractive. Infrastructure development is needed.

3. Biomass market development on regional scale; larger-scale conversion units with increasing fuel flexibility are deployed; increasing average transport distances further improved economies of scale. Increasing costs of biomass supplies make more energy-efficient conversion facilities necessary as well as feasible. Policy support measures such as feed-in tariffs are usually already needed to develop into this stage.
4. Development of national markets with increasing number of suppliers and buyers; creation of a market place; increasingly complex logistics. Often increased availability due to improved supply systems and access to markets. Price levels may therefore even decrease (see, e.g. Hillring, 2002).

5. Increasing scale of markets and transport distances, including cross-border transport of biofuels; international trade of biomass resources (and energy carriers derived from biomass). Biomass is increasingly becoming a globally traded energy commodity (see, e.g. Vesterinen and Alakangas, 2002; Faaij et al., 2002). In some cases, conflicts arise due to profound differences in national support schemes such as subsidies, taxes and environmental legislation. 
6. Growing role for dedicated fuel supply systems (biomass production largely or only for energy purposes). So far, dedicated crops are mainly grown because of agricultural interests and support (subsidies for farmers, use of set-aside subsidies), which concentrate on oil seeds (like rapeseed) and surplus food crops (cereals and sugar beet). Perennial grasses, poplar and plantation forest receive attention in various countries.

A clear European strategy in these matters does not exist however. Fundamental debate is ongoing on the desirability of using large surfaces of land for bioenergy, possibly conflicting with a vision where agriculture transforms to low input (and less productive) management systems on a large scale. It is, however, clear that active crop production (largely for) energy purpose is required to meet the ambitions for bio-energy in Europe.

\subsection{Conversion technologies: power and heat}

A wide variety of technologies is deployed for energy production from biomass. Production of heat (domestic and industrial), electricity (or combined heat and power-CHP) and transport fuels is possible through a portfolio of technologies (see Fig. 2). Below, we will discuss the most important technologies, which are deployed in Europe with respect to their status and (generic) performance levels. We will also discuss some key options which are under development and that could play an important role in the coming decades.
In Sections 2.2.1-2.2.4, the different technological routes for production of electricity and heat are briefly discussed. Table 2 summarizes some generic key performance figures (costs, efficiency and resulting costs ranges of power and heat produced for given assumptions) as well as the global status for the respective technologies in Europe.

\subsubsection{Digestion}

- Biogas: Anaerobic digestion of biomass has been demonstrated and applied commercially with success in a multitude of situations and for a variety of feedstocks such as organic domestic waste, organic industrial wastes, manure, sludges, etc. Digestion has a low overall electrical efficiency (roughly $10-15 \%$, strongly depending on the feedstock) and is particularly suited for wet biomass materials. Digestion has been deployed for a long time in the food and beverage industry to process wastewater with high loads of organic matter. Currently, advanced, largescale, systems are developed for wet industrial waste streams and applied in many countries. Especially Denmark and the Netherlands have a strong position with advanced digestion systems used for processing various wet waste streams.

- Landfill gas utilization: A specific source of biogas is landfills. The production of methane-rich landfill gas from landfill sites makes a significant contribution to atmospheric methane emissions. In many situations, the collection of landfill gas and production of electricity by converting this gas in gas engines is profitable and the application of such systems has

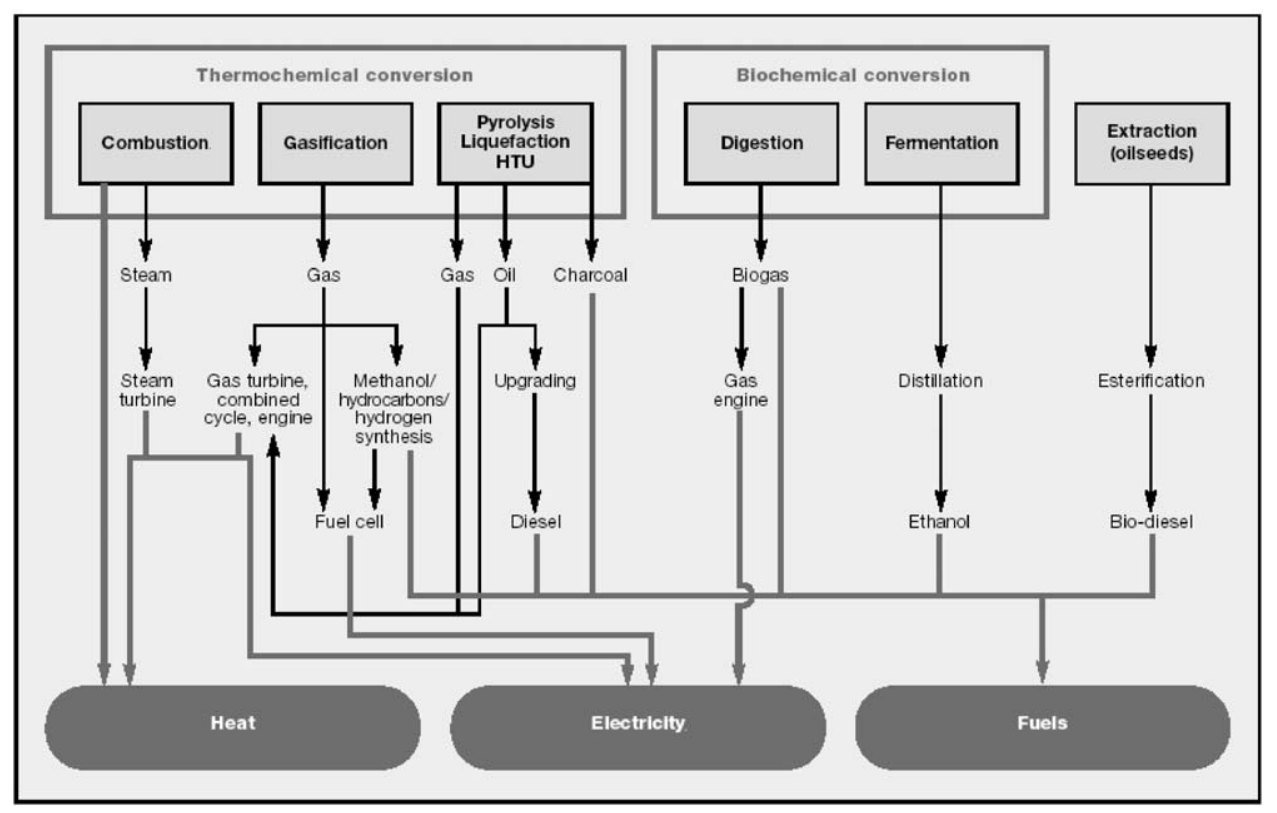

Fig. 2. Main conversion options for biomass to secondary energy carriers (Turkenburg et al., 2000). Some categories represent a wide range of technological concepts as well as capacity ranges at which they are deployed, which are dealt with further in the main text. 
Table 2

Global overview of current and projected performance data for the main conversion routes of biomass to power and heat and summary of technology status and deployment in the European context; based on a variety of literature sources (i.e. van Loo and Koppejan, 2002; van den Broek et al., 1996; Kaltschmitt et al., 1998; Faaij et al., 1998a, b; DOE, 1998)

\begin{tabular}{|c|c|c|c|c|c|}
\hline $\begin{array}{l}\text { Conversion } \\
\text { option }\end{array}$ & & $\begin{array}{l}\text { Typical capacity } \\
\text { range }\end{array}$ & $\begin{array}{l}\text { Net efficiency } \\
\text { (LHV basis) }\end{array}$ & $\begin{array}{l}\text { Investment cost } \\
\text { ranges }(€ / \mathrm{kW})\end{array}$ & Status and deployment in Europe \\
\hline \multirow[t]{2}{*}{$\begin{array}{l}\text { Biogas } \\
\text { production }\end{array}$} & $\begin{array}{l}\text { Anaerobic } \\
\text { digestion }\end{array}$ & Up to several $\mathrm{MW}_{\mathrm{e}}$ & $\begin{array}{l}10-15 \% \\
\text { (electrical) }\end{array}$ & & $\begin{array}{l}\text { Well-established technology. Widely } \\
\text { applied for homogeneous wet organic } \\
\text { waste streams and wastewater. To a lesser } \\
\text { extent used for heterogeneous wet wastes } \\
\text { such as organic domestic wastes. }\end{array}$ \\
\hline & Landfill gas & $\begin{array}{l}\text { Generally several } \\
100 \mathrm{sW}_{\mathrm{e}}\end{array}$ & $\begin{array}{l}\text { Gas engine } \\
\text { efficiency }\end{array}$ & & $\begin{array}{l}\text { Very attractive GHG mitigation option. } \\
\text { Widely applied in EU and in general part } \\
\text { of waste treatment policies of most } \\
\text { countries. }\end{array}$ \\
\hline \multirow[t]{5}{*}{ Combustion } & Heat & Domestic $1-5 \mathrm{MW}_{\text {th }}$ & $\begin{array}{l}\text { From very low } \\
\text { (classic } \\
\text { fireplaces) up to } \\
70-90 \% \text { for } \\
\text { modern } \\
\text { furnaces. }\end{array}$ & $\begin{array}{l}\sim 100 / \mathrm{kW}_{\mathrm{th}} \\
300-700 / \mathrm{kW}_{\mathrm{th}} \text { for } \\
\text { larger furnaces. }\end{array}$ & $\begin{array}{l}\text { Classic firewood use still widely deployed } \\
\text { in Europe, but decreasing. Replacement } \\
\text { by modern heating systems (i.e. } \\
\text { automated, flue gas cleaning, pellet firing) } \\
\text { in, e.g. Austria, Sweden, Germany } \\
\text { ongoing for years. }\end{array}$ \\
\hline & $\mathrm{CHP}$ & $0.1-1 \mathrm{MW}_{\mathrm{e}}$ & $\begin{array}{l}60-90 \% \\
\text { (overall) }\end{array}$ & & $\begin{array}{l}\text { Widely deployed in Scandinavia countries, } \\
\text { Austria, Germany and to a lesser extent } \\
\text { France. In general increasing scale and } \\
\text { increasing electrical efficiency over time. }\end{array}$ \\
\hline & & $1-10 \mathrm{MW}_{\mathrm{e}}$ & $\begin{array}{l}80-100 \% \\
\text { (overall) }\end{array}$ & & \\
\hline & Stand alone & $20-100 \mathrm{~s} \mathrm{MW}_{\mathrm{e}}$ & $\begin{array}{l}20-40 \% \\
\text { (electrical) }\end{array}$ & $2.500-1600$ & $\begin{array}{l}\text { Well-established technology, especially } \\
\text { deployed in Scandinavia; various } \\
\text { advanced concepts using Fluid Bed } \\
\text { technology giving high efficiency, low } \\
\text { costs and high flexibility commercially } \\
\text { deployed. } \\
\text { Mass burning or waste incineration goes } \\
\text { with much higher capital costs and lower } \\
\text { efficiency, widely applied in countries like } \\
\text { the Netherlands, Germany a.o. }\end{array}$ \\
\hline & $\begin{array}{l}\text { Co- } \\
\text { combustion }\end{array}$ & $\begin{array}{l}\text { Typically } 5-20 \mathrm{MW}_{\mathrm{e}} \\
\text { at existing coal-fired } \\
\text { stations. } \\
\text { Higher for new } \\
\text { multi-fuel power } \\
\text { plants. }\end{array}$ & $\begin{array}{l}30-40 \% \\
\text { (electrical) }\end{array}$ & $\begin{array}{l}\sim 250+\text { costs of } \\
\text { existing power } \\
\text { station. }\end{array}$ & $\begin{array}{l}\text { Widely deployed in many EU countries. } \\
\text { Interest for larger biomass co-firing shares } \\
\text { and utilization of more advanced options } \\
\text { (e.g. by feeding fuel gas from gasifiers) is } \\
\text { growing in more recent years. }\end{array}$ \\
\hline \multirow[t]{3}{*}{ Gasification } & Heat & $\begin{array}{l}\text { Usually smaller } \\
\text { capacity range } \\
\text { around } 100 \mathrm{~s} \mathrm{~kW}_{\mathrm{th}}\end{array}$ & $\begin{array}{l}80-90 \% \\
\text { (overall) }\end{array}$ & $\begin{array}{l}\text { Several } 100 \mathrm{~s} / \mathrm{kW}_{\mathrm{th}} \\
\text { depending on } \\
\text { capacity. }\end{array}$ & $\begin{array}{l}\text { Commercially available and deployed; but } \\
\text { total contribution to energy production in } \\
\text { the EU is very limited. }\end{array}$ \\
\hline & $\begin{array}{l}\text { CHP gas } \\
\text { engine }\end{array}$ & $0.1-1 \mathrm{MW}_{\mathrm{e}}$ & $15-30 \%$ & $\begin{array}{l}3.000-1.000 \\
\text { (depends on } \\
\text { configuration) }\end{array}$ & $\begin{array}{l}\text { Various systems on the market. } \\
\text { Deployment limited due to relatively high } \\
\text { costs, critical operational demands and } \\
\text { fuel quality. }\end{array}$ \\
\hline & $\mathrm{BIG} / \mathrm{CC}$ & $30-100 \mathrm{MW}_{\mathrm{e}}$ & $\begin{array}{l}40-50 \% \text { (or } \\
\text { higher; electrical } \\
\text { efficiency) }\end{array}$ & $\begin{array}{l}5.000-3.500 \text { (demos), } \\
2.000-1.000 \text { (longer } \\
\text { term, larger scale) }\end{array}$ & $\begin{array}{l}\text { Demonstration phase at } 5-10 \mathrm{MW}_{\mathrm{e}} \text { range } \\
\text { obtained. Rapid development in the } \\
\text { nineties has stalled in recent years. First } \\
\text { generation concepts prove capital } \\
\text { intensive. }\end{array}$ \\
\hline Pyrolysis & Bio-oil & $\begin{array}{l}\text { Generally smaller } \\
\text { capacities are } \\
\text { proposed of several } \\
100 \mathrm{~s} \mathrm{~kW} \text { th. }\end{array}$ & $\begin{array}{l}60-70 \% \text { heat } \\
\text { content of bio- } \\
\text { oil/feedstock. }\end{array}$ & & $\begin{array}{l}\text { Not commercially available; mostly } \\
\text { considered a pre-treatment option for } \\
\text { longer distance transport. }\end{array}$ \\
\hline
\end{tabular}

Note: Due to the variability of data in the various references and conditions assumed, all cost figures should be considered as indicative. Some key assumptions for the estimated production cost ranges are given in footnotes; generally they reflect European conditions. 
become widespread. The benefits are obvious: useful energy carriers are produced from gas that would otherwise contribute to a build-up of GHGs in the atmosphere (Faaij et al., 1998a, b). This makes landfill gas utilization in general a very attractive GHG mitigation option and is widely adopted throughout the EU.

\subsubsection{Combustion}

- Domestic heating: A classic application of biomass combustion is heat production for domestic applications. This is still a major market for biomass for domestic heating in countries like Austria, France, Germany and Sweden. Use of wood in open fireplaces and small furnaces in houses is generally poorly registered, but estimated contributions to meet heat demand are considerable in the countries mentioned. Traditional use of wood generally has a low efficiency (sometimes as low as $10 \%$ ) and generally goes with considerable emissions of, e.g., dust and soot. Technology development has led to the application of strongly improved heating systems, which are for example automated, have catalytic gas cleaning and make use of standardized fuel (such as pellets). The efficiency benefit compared to, e.g., open fireplaces is considerable: open fireplaces may even have a negative efficiency over the year (due to heat losses through the chimney), while advanced domestic heaters can obtain efficiencies of $70-90 \%$ with strongly reduced emissions. The application of such systems is especially observed in, e.g., Scandinavia, Austria and Germany. In Sweden, in particular, a significant market has developed for biomass pellets, which are fired in automated firing systems (van Loo and Koppejan, 2002).

- District heating and CHP: The application of biomass-fired district heating is widely applied in Scandinavian countries and Austria. In Scandinavia, biomass-fired CHP really took off in the eighties as a result of national climate and energy policies. In the first stages, retrofits of existing coal-fired boilers were popular. Over time, the scale of CHP systems shows an increasing trend, with apparent advantages as higher electrical efficiencies and lower costs (Visser, 2004). This was also combined with a developing biomass market, allowing for more competitive and longer distance supplies of biomass resources (especially forest residues) (Hillring, 2002). During the nineties, Denmark deployed a major program for utilizing straw. Various technical concepts were developed and deployed such as the so-called cigar burners combined with efficient straw baling equipment, transport and storage chains. Other innovations were needed to deal with the difficult combustion characteristics of straw such as the high alkali and chlorine content. This led to complex boiler concepts, e.g. involving two-stage combustion, and also new pre-treatment techniques such as straw washing (Nikolaisen et al., 1998). Austria, another leading country in deploying biomass-fired CHP focused on smaller-scale systems on the village level, generally combined with local fuel supply systems. All countries mentioned have colder climates, making CHP economically attractive. Furthermore, involvement of local communities has proven important. Municipalities and forest owners are often the owners of the CHP plants. Energy costs of those systems are usually somewhat higher. Local societal support is generally strong though, especially due to the employment and expenditures that benefit the local community. High labor costs also led to high degrees of automation though, with unmanned operation typical for many of the newer facilities (Serup et al., 1999).

- Larger-scale combustion of biomass for the production of electricity (plus heat and process steam) is applied commercially worldwide. Many plant configurations have been developed and deployed over time. Basic combustion concepts include pile burning, various types of grate firing (stationary, moving and vibrating), suspension firing and fluidized bed concepts. The key sector for the application for biomass combustion for power generation is the paper and pulp industry for combustion of black liquor and waste incineration. Conventional boilers for combined production of power and process steams and recovery of pulping chemicals is common technology for the pulp and paper sector. Waste incinerators were widely deployed starting in the eighties in countries like Germany and the Netherlands, combined with very stringent emission standards. Typical technologies deployed are large-scale (i.e. around 1 Mtonne capacity per plant per year) moving grate boilers (which allow mass burning of very diverse waste properties), low steam pressures and temperatures (to avoid corrosion) and extensive flue gas cleaning. Typical electrical efficiencies are between $15 \%$ and over $20 \%$. Mass burning became the key waste-to-energy technology deployed in Europe, and is also relatively expensive with treatment costs in the range of $50-150 € /$ tonne (offset by tipping fees) (Faaij et al., 1997a,b). Typical capacities for stand-alone biomass combustion plants (typically using wood such as forest residues, as fuel) range between 20 and $50 \mathrm{MW}_{\mathrm{e}}$, with related electrical efficiencies in the $25-30 \%$ range. Such plants are only economically viable when fuels are available at low costs or when a carbon tax or feed-in tariff for renewable electricity is in place. In recent years, advanced combustion concepts have penetrated the market. The application of fluidized bed technology and advanced gas cleaning allows for efficient and production of electricity (and heat) from biomass. On a scale of about $50-80 \mathrm{MW}_{\mathrm{e}}$, electrical efficiencies of 
30-40\% are possible (van Loo and Koppejan, 2002; van den Broek et al., 1996). Finland is on the cutting edge of the field with development and deployment of bubbling fluidized bed (BFB) and circulating fluidized bed (CFB) boilers with high fuel flexibility, low costs, high efficiency and deployed on a large scale. One of the latest plants realized in Finland has a capacity of some $500 \mathrm{MW}_{\text {th }}(!)$ and is co-fired with a portfolio of biomass fuels, partly supplied by water transport.

- Co-combustion: Co-combustion of biomass, in particular, in coal-fired power plants is the single largest growing conversion route for biomass in many EU countries (e.g. in Spain, Germany and the Netherlands to name a few). The advantages of co-firing are apparent: the overall electrical efficiency is high due to the economies of scale of the existing plant (usually around $40 \%$ ) and investment costs are low up to negligible when high-quality fuels as pellets are used. Also, directly avoided emissions are high due to direct replacement of coal. Combined with the fact that many coal-fired power plants in operation are fully depreciated, this makes co-firing usually a very attractive GHG mitigation option. In addition, biomass firing leads to lowering sulfur and other emissions (see, e.g. Meuleman and Faaij, 1999). Development of co-firing was also strongly supported by various research efforts, such as the APAS program funded by the EC that has led to testing the performance, technical and environmental implications of co-firing a multitude of boilers concepts with a wide variety of biomass fuels (varying from sludge to clean wood). Generally, relatively low cofiring shares (up to about $10 \%$ of thermal input) are deployed with very limited consequences for boiler performance and maintenance. Because many plants are now equipped with some co-firing capacity interest for higher co-firing shares (e.g. up to $40 \%$ ) is rising. Consequently, technical implications for, e.g., feeding lines and boiler performance are more severe and current development efforts focus on those issues. Power plants capable of firing, e.g., natural gas, coal and various biomass streams are built in Denmark (e.g. the Avedore plant) with the benefit of gaining economies of scale as well as reduced fuel supply risks (van Loo and Koppejan, 2002).

\subsubsection{Gasification}

Gasification as a general means to convert a diversity of solid fuels to combustible gas or syngas has received considerable attention in the eighties worldwide and also in Europe. The use of gasification for production of fuels will be discussed further in Section 2.3. In this section, we will first focus on production of heat and power deploying biomass gasification. We will distinguish between smaller-scale gasification (i.e. in the 10 s of $\mathrm{kW}_{\text {th }}$ to around $1 \mathrm{MW}_{\text {th }}$ capacity range; generally involving fixed bed gasification concepts) and largerscale gasification, which generally makes use of fluidized bed reactor concepts.

- Smaller-scale gasification: At the end of the 80s and the beginning of the nineties, small-scale gasification received major support. Downdraft or updraft, fixed bed gasifiers with capacities of less than a $100 \mathrm{~kW}_{\text {th }}$ up to a few $\mathrm{MW}_{\text {th }}$ were developed and tested for smallscale power and heat generation using diesel or gas engines. Heat production using (small) gasifier has proven as commercially established. Finland in particular was successful in the 80s deploying smaller-scale gasifiers for heat production (Bioneer). A wide array of concepts for gasifiers, gas cleaning and system integration for such concepts was proposed and tested in a wide variety of conditions. Technology was also exported to many developing countries with support from international bodies as the World Bank. The key drivers here were rural development and electrification. So far, despite the major efforts, investments and large number of demonstration units, the concept of small-scale gasification linked to gas or diesel engines never took off. Small (fixed bed) gasifiers coupled to diesel/gas engines (typically for $100-200 \mathrm{~kW}_{\mathrm{e}}$ systems with an approximate, modest, electrical efficiency of $15-25 \%$ ) are available on the market. However, the critical demands of small-scale gasifiers to fuel quality (preferably standardized and hence more expensive fuel such as pellets), the required careful operation and high costs especially for effective gas cleaning, given the severe emission standards in the $\mathrm{EU}$, have so far hampered their wide deployment (Kaltschmitt et al., 1998; Stassen, 1995). Possibly, on the longer term, standardized gasification systems ('pre-packaged') using fuel cells and micro-turbines could mean a breakthrough for small-scale electricity production from biomass, but such systems need further development and will depend on cheap and reliable fuel cells and again, major advances in small-scale gas cleaning, because such devices are even more sensitive to gas quality than internal combustion engines.

- Larger-scale (CFB) biomass gasification: Larger gasifiers (i.e. over several $10 \mathrm{~s} \mathrm{MW}_{\text {th }}$ capacity are generally associated with (Circulating) fluidized bed concepts. At atmospheric pressure (ACFB) gasifiers are used for production of (raw) fuel gas and process heat (e.g. in Italy, Austria, Sweden and Germany) but not in very large numbers. Biomass integrated gasification/combined cycle (BIG/CC) systems combine flexibility with respect to fuel characteristics with a high electrical efficiency. Electrical efficiencies around $40 \%$ (lower heating value (LHV) basis) are possible on a scale of about $30 \mathrm{MW}_{\mathrm{e}}$ on shorter term (Consonni and Larson, 1994a, b; Faaij et al., $1997 \mathrm{a}, \mathrm{b}) . \mathrm{BIG} / \mathrm{CC}$ became the center of attention in 
EC and various national programs in the first half of the nineties. The promise of this technology, allowing for high electrical efficiency at modest scales combined with modest capital costs, resulted in a variety of research and demonstration initiatives. Furthermore, the CFB technology principally allows for high fuel flexibility and inherent to the $\mathrm{BIG} / \mathrm{CC}$ concepts low emissions to air can be obtained. Demonstration projects were launched in various countries and for various gasification concepts: in Brazil a global environment facility (GEF)/World Bank supported project was set up to demonstrate a $30 \mathrm{MW}_{\mathrm{e}}$ Atmospheric BIG/CC unit fired with cultivated Eucalyptus (Elliott and Booth, 1993). In the same period in Sweden, the first pressurized $\mathrm{BIG} / \mathrm{CC}$ unit the BIOFLOW pilot-project), based on a pressurized gasification process has gained several thousands of hours of operational experience (Stahl, 1997). Three other demo-units around the $6-10 \mathrm{MW}_{\mathrm{e}}$ scale were supported by the EC as THERMIE projects, all aimed at demonstrating $\mathrm{BIG} / \mathrm{CC}$ technology using specially cultivated wood produced via SRC systems (Kaltschmitt et al., 1998). As a result, one atmospheric BIG/CC system was commissioned in 2000 in Yorkshire, UK (the so-called ARBRE project). An important project in the US is the demonstration of the indirect FERCO gasification concept at the existing Burlington power station. In addition, a variety of national initiatives were launched aimed at pre-commercial or demonstration units of $\mathrm{BIG} / \mathrm{CC}$ technology (in particular in Scandinavia and the Netherlands). However, in practice, the realization of the demonstration projects proved to be difficult. Costs of first generation units proved to be very high. The first generation of $\mathrm{BIG} / \mathrm{CC}$ systems shows high unit capital costs. Depending on the scale, price levels of $5000-3500 € / \mathrm{kW}_{\mathrm{e}}$ are quoted (Faaij et al., 1998a,b), which is still far from the desired $1500-2000 € / \mathrm{kW}_{\mathrm{e}}$, which could bring BIG/CC in a competitive area. Various technological issues (e.g. concerning pre-treatment and tar removal) still need to be resolved. Later in the nineties, many utilities involved faced the consequences of the rapid liberalization process in the energy sector and expensive demonstration activities proved to be hard to pursue. Various demonstration units (such as ARBRE and BIOFLOW) were put out of operation recently. In total, co-firing and proven combustion technology (which also develops over time) are generally favored by the risk weary energy sector. This has led to the remarkable situation of a stalling development of a technology that, on a somewhat longer term, is capable of producing power from biomass at competitive price levels. At a somewhat larger scale (over $100 \mathrm{MW}_{\mathrm{e}}$ ) and considering the ongoing improvement of gas turbine technology, the cost reduction potential of $\mathrm{BIG} / \mathrm{CC}$ systems is considerable, as has been evaluated by numerous studies (Williams and Larson, 1996; Faaij et al., 1998a, b; Solantausta et al., 1996). The combination of high electrical efficiencies with relatively low unit capital costs can make the use of cultivated biomass as feedstock economically feasible for many areas in the world. So far, however, development has stalled.

- Gasification for co-firing: Gasification is also a route toward large co-firing shares of existing (coal-fired) power plants, avoiding the need for additional solid fuel feeding lines and allowing for better control of the combustion process. Successful deployment of (A)CFB gasifiers is recently shown in co-firing schemes (e.g. Lahti in Finland and Amer in the Netherlands) (van Loo and Koppejan, 2002). An interesting alternative for fuel gas produced through biomass gasification is its use in existing (or new) natural gas-fired CCs. In this way, economies of scale are utilized resulting in low costs and (very) high overall electrical efficiencies (currently up to $60 \%$ for natural gas-fired CCs; resulting in electrical efficiencies well over $50 \%$ for biomass-based electricity production preceded by gasification). At the same time, a more secure fuel supply is obtained since one can vary the share of fuel gas and natural gas fired (Rodriguez et al., 2003). So far, this option has not been demonstrated anywhere in the world, but research efforts are increased and it could prove to be of major importance on short term given that cofiring opportunities at existing coal-fired power plants are increasingly utilized already.

\subsubsection{Production of bio-oils: pyrolysis and liquefaction processes}

Pyrolysis converts biomass at temperatures around $500{ }^{\circ} \mathrm{C}$, in the absence of oxygen, to liquid (bio-oil), gaseous and solid (charcoal) fractions. With flash pyrolysis techniques (or so-called fast pyrolysis) the liquid fraction can be maximized (up to $70 \%$ of the thermal biomass input). Bio-oil contains about $40 \mathrm{wt} \%$ of oxygen and is corrosive and acidic. In principle, crude bio-oil can in principle be used for firing engines and turbines. The crude oil can also be upgraded (e.g. via hydrogenation) in order to reduce the oxygen content. But upgrading comes with both economic and energy penalties. Pyrolysis and upgrading technology is largely in the pilot phase (Bridgewater, 1998). Liquefaction (conversion under high pressure) and hydro thermal upgrading (HTU) are other ways of producing 'raw intermediate' liquids from biomass (Naber et al., 1997).

To date, pyrolysis (and even more liquefaction options) is less well developed than gasification. Major attention since the end of the eighties/beginning of the nineties was especially caused by the potential deployment of this technology on small scale in rural areas and 
the use of the product as feedstock for the chemical industry. Reducing transport costs because of the higher energy density of bio-oil compared to untreated biomass was used as another key argument.

Although considerable experience was gained over time, still, very few successful pilot schemes were realized (a prime example shown by Fortum, a Finnish Oil company). Actual market implementation is so far negligible. Pyrolysis now receives most attention as a pre-treatment step for long-distance transport of bio-oil that can be used in further conversion (e.g. efficient power generation or oil gasification for syngas production).

\subsection{Conversion technologies: biofuels for the transport sector}

As follows from Fig. 2, three main routes can be distinguished to produce fuels (for the transport sector) from biomass: extraction from oil seeds, production of ethanol via fermentation and production of synfuels via gasification. Sections 2.3.1-2.3.3 briefly discuss the technological routes. Table 3 summarizes key performance figures (costs, efficiency and resulting cost ranges of biofuel produced for given assumptions).

\subsubsection{Extraction and production of esters from oilseeds}

Oilseeds, like rapeseed, can be extracted and converted to esters and are well suited to replace diesel. Rapeseed production and subsequent esterification (using methanol to produce rapeseed methyl ester or RME) and distribution is established technology in Europe. Significant quantities of RME are produced in the EU (concentrating in Germany, France and to a lesser extent in Austria and Italy). RME, however, requires substantial subsidies to compete with diesel, also on the longer term. Subsidies in Europe generally consist of a combination of farm subsidies (e.g. for producing non-food crops) and tax exemption of the fuel itself. The latter implies about a factor of 3-4 subsidy compared to conventional diesel or gasoline production costs (see also Table 3). Key drivers for the implementation of RME schemes are rural employment and the flexible nature of the crop because it can easily replace conventional food crops when desired. Energy balances of RME fuel chains are unfavorable when compared to perennial crops, meaning the net energy production per hectare is low (in the past in some cases the balance was negative) (Kaltschmitt et al., 1996; Biewinga and van der Bijl, 1996). On longer term, energy balances and economic performance can be improved to some extent, particularly by using residue straw for efficient heat and power production.

\subsubsection{Fermentation: production of ethanol}

- Ethanol from sugar and starch: Production of ethanol via fermentation of sugars is a classic conversion route, which is applied for sugar cane, maize and cereals on a large scale, especially in Brazil, the US and France. Sweden and Spain have more modest production levels of ethanol. Ethanol is generally mixed with gasoline, which, at low percentages, can be done without adaptations to the current vehicle fleet. Ethanol has the advantage that it lowers $\mathrm{NO}_{x}$ and dust emissions to some extent compared to gasoline use only. The US and European programs are particularly used for converting surpluses of food crops to a useful (by) product. Ethanol production from food crops like maize and cereals is, however, far from competitive when compared to gasoline and diesel prices and it is not likely this will change on the longer term.

- Ethanol from ligno-cellulosic (woody) biomass: Hydrolysis of ligno-cellulosic biomass can open the way toward low cost and efficient production of ethanol from ligno-cellulosic biomass. The development of various hydrolysis techniques has gained major attention over the past 8 years or so, particularly in Sweden and the US. However, cheap and efficient hydrolysis processes are still under development and some fundamental issues need to be resolved. The conversion is more difficult than for sugar and starch because from ligno-cellulosic materials, first sugars need to be produced via hydrolysis. This can be done through acid treatment or via enzymatic pathways, the first route being relatively expensive and inefficient and the second technologically unproven. In addition, the pre-treatment of woody biomass materials for further processing is a technical challenge. In addition, production of the enzymes required is currently expensive. Simulaneous conversion and production of enzymes may reduce those costs considerably on longer term. Assuming, however, that those issues are resolved and ethanol production is combined with efficient electricity production from unconverted wood fractions (lignine in particular), ethanol costs could come close to current gasoline prices (Lynd, 1996): as low as 6-7€/GJ ethanol produced assuming biomass costs of about $2 € / \mathrm{GJ}$. Overall system energy efficiencies rise well above $60 \%$ (on LHV basis). (Hamelinck et al., 2003) come to comparable, though somewhat more careful, conclusions. For the agricultural sector and agro-food industry, this technology is already of interest to boost the competitiveness of existing production facilities (e.g. by converting available crop and process residues), which provides drivers for both industry and agriculture reasons to support this technology. Therefore, conversion of ligno-cellulosic material to ethanol is receiving support in the EC programs, as well as in the national programs of Sweden (one of the world's frontrunners in this area) 
Table 3

Global overview of current and projected performance data for the main conversion routes of biomass to fuels (e.g. based on: Faaij and Hamelinck, 2002; Hamelinck and Faaij, 2002; Tijmensen et al., 2002; De Jager et al., 1998; Ogden et al., 1999; Wyman et al., 1993; International Energy Agency, 1994; Williams et al., 1995, etc.)

\begin{tabular}{|c|c|c|c|c|c|c|c|}
\hline \multirow[t]{2}{*}{ Concept } & \multicolumn{2}{|c|}{ Energy efficiency $(\mathrm{HHV})+$ energy inputs } & \multicolumn{2}{|c|}{$\begin{array}{l}\text { Investment costs }\left(€ / \mathrm{kW}_{\text {th }} \text { input }\right. \\
\text { capacity) }\end{array}$} & \multirow[t]{2}{*}{$\begin{array}{l}\text { O\&M (\% of } \\
\text { investment) }\end{array}$} & \multicolumn{2}{|c|}{$\begin{array}{l}\text { Estimated production } \\
\text { costs }\left(€ / \mathrm{GJ}_{\text {fuel }}\right)\end{array}$} \\
\hline & Short term & Long term & Short term & Long term & & $\begin{array}{l}\text { Shorter } \\
\text { term }\end{array}$ & Longer term \\
\hline $\begin{array}{l}\text { Hydrogen: via biomass gasification and } \\
\text { subsequent syngas processing. Combined } \\
\text { fuel and power production possible for } \\
\text { production of liquid hydrogen additional } \\
\text { electricity use should be taken into } \\
\text { account. }\end{array}$ & $\begin{array}{l}60 \% \text { (fuel only) } \\
\left(+0.19 \mathrm{GJ}_{\mathrm{e}} / \mathrm{GJ} \mathrm{H} 2\right. \\
\text { for liquid hydrogen) }\end{array}$ & $\begin{array}{l}55 \% \text { (fuel) } 6 \% \\
\text { (power) }(+ \\
0.19 \mathrm{GJ}_{\mathrm{e}} / \mathrm{GJ} \mathrm{H} 2 \text { for } \\
\text { liquid hydrogen) }\end{array}$ & $\begin{array}{l}480 \text { ( }+48 \text { for } \\
\text { liquefying) }\end{array}$ & $\begin{array}{l}360(+33 \text { for } \\
\text { liquefying })\end{array}$ & 4 & $9-12$ & $4-8$ \\
\hline $\begin{array}{l}\text { Methanol: via biomass gasification and } \\
\text { subsequent syngas processing. Combined } \\
\text { fuel and power production possible. }\end{array}$ & $55 \%$ (fuel only) & $\begin{array}{l}48 \% \text { (fuel) } 12 \% \\
\text { (power) }\end{array}$ & 690 & 530 & 4 & $10-15$ & $6-8$ \\
\hline $\begin{array}{l}\text { Fischer-Tropsch liquids: via biomass } \\
\text { gasification and subsequent syngas } \\
\text { processing. Combined fuel and power } \\
\text { production possible. }\end{array}$ & $45 \%$ (fuel only) & $\begin{array}{l}45 \% \text { (fuel) } 10 \% \\
\text { (power) }\end{array}$ & 720 & 540 & 4 & $12-17$ & $7-9$ \\
\hline $\begin{array}{l}\text { Ethanol from wood: production takes } \\
\text { place via hydrolysis techniques and } \\
\text { subsequent fermentation and includes } \\
\text { integrated electricity production of } \\
\text { unprocessed components. }\end{array}$ & $\begin{array}{l}46 \% \text { (fuel), } 4 \% \\
\text { (power) }\end{array}$ & $\begin{array}{l}53 \% \text { (fuel), } 8 \% \\
\text { (power) }\end{array}$ & 350 & 180 & 6 & $12-17$ & $4-7$ \\
\hline $\begin{array}{l}\text { Ethanol from sugar: production via } \\
\text { fermentation; some additional energy } \\
\text { inputs are needed for distillation. As } \\
\text { feedstock, sugar beets are assumed. }\end{array}$ & $\begin{array}{l}43 \% \text { (fuel only), } \\
0.065 \mathrm{GJ}_{\mathrm{e}}+0.24 \\
\mathrm{GJ}_{\mathrm{th}} / \mathrm{GJ} \\
\mathrm{EtOH}\end{array}$ & $\begin{array}{l}43 \% \text { (fuel only), } \\
0.035 \mathrm{GJ}_{\mathrm{e}}+0.18 \\
\mathrm{GJ}_{\text {th }} / \mathrm{GJ} \text { EtOH }\end{array}$ & 290 & 170 & 5 & $25-35$ & $20-30$ \\
\hline $\begin{array}{l}\text { Bio-diesel RME: takes place via extraction } \\
\text { (pressing) and subsequent esterification. } \\
\text { Methanol is an energy input. For the total } \\
\text { system it is assumed that surpluses of } \\
\text { straw are used for power production. }\end{array}$ & \multicolumn{2}{|c|}{$\begin{array}{l}\text { output Efficiency power generation on } \\
\text { shorter term: } 45 \% \text {, on longer term: } 55 \%\end{array}$} & $\begin{array}{l}150(+450 \text { for } \\
\text { power } \\
\text { generation } \\
\text { from straw })\end{array}$ & $\begin{array}{l}110(+250 \text { for } \\
\text { power } \\
\text { generation } \\
\text { from straw })\end{array}$ & 4 & $25-40$ & $20-30$ \\
\hline
\end{tabular}

Note: Assumed biomass price of clean wood: $2 € /$ GJ. RME cost figures varied from $20 € /$ GJ (short term) to $12 € /$ GJ (longer term), for sugar beet a range of $12-8 € / G J$ is assumed. All figures exclude distribution of the fuels to fueling stations.

For equipment costs, an interest rate of $10 \%$, economic lifetime of 15 years is assumed. Capacities of conversion unit are normalized on $400 \mathrm{MW}_{\text {th }}$ input on shorter term and $1000 \mathrm{MW}_{\text {th }}$ input on longer term.

Diesel and gasoline production costs vary strongly depending on the oil prices, but for indication: recent cost ranges are between 4 and $7 € / G J$. Longer-term projections give estimates of roughly $6-10 € /$ GJ. Note that the transportation fuel retail prices are usually dominated by taxation and can vary between 50 and 130 Euroct./1 depending on the country in question.

Due to the variability of data in the various references and conditions assumed, all cost figures should be considered as indicative. Footnotes summarize assumptions, generally reflecting EU conditions.

and to a lesser extent in countries like the UK, Spain and the Netherlands.

\subsubsection{Methanol, hydrogen and hydrocarbons via gasification}

Partly as a result of the oil crises, the interest for biomass-derived syngas for production of transport fuels (such as methanol) was already pursued in the eighties. Pressurized gasification for methanol production from biomass was tested and developed in France and Sweden. Kemira (a Finnish company, e.g., active in production of fertilizers) installed a large-scale CFB gasifier in Oulu (Finland) for producing syngas for an ammonia factory. The gasifier was later shut down though due to low costs of fossil fuels. Also noteworthy is the installed gasification capacity (entrained flow) at Schwarze Pumpe (former East Germany) for producing methanol from waste streams, which is a major industrial experience with this technology. Low energy prices deteriorated the position of advanced gasification technologies for large-scale applications (Kaltschmitt et al., 1998). Renewed attention for using gasification technology for production of transport fuels, in particular hydrocarbons produced via Fischer-Tropsch (FT) process, resulting in synthetic (liquid) hydrocarbons or diesel (Netherlands, Germany) and hydrogen (EC). Although this seems a viable development given the technoeconomic potential of such concepts (see also Table 3), the technological challenges remain and are likely to be more complex than for $\mathrm{BIG} / \mathrm{CC}$ concepts because gas 
cleaning needs to be even more effective in order to protect downstream catalytic gas processing equipment.

Once clean syngas is available, known process technology for producing methanol (or dimethylether-DME), FT liquids and hydrogen can be applied. However, so far no commercial biomass fed facilities are operational in either Europe or the rest of the world for doing so. The main challenges in this area are gas cleaning, scale-up of processes and process integration. Overall energetic efficiencies of relatively 'conventional' production facilities, could be close to $60 \%$ (on a scale of about $400 \mathrm{MW}_{\text {th }}$ input). Deployment on a large scale (e.g. over $1000 \mathrm{MW}_{\text {th }}$ ) is required to gain the necessary economies of scale. In total, however, this (set of) option(s) has a strong position from both efficiency and economic perspective (see Table 3 and Tijmensen et al., 2002; Hamelinck and Faaij, 2002; Williams et al., 1995).

More recent technological concepts, such as liquidphase methanol production and once-through FT synthesis (combined with electricity generation) and new gas separation technology offer potentially lower production costs and higher overall energy efficiencies.

More research, demonstration and development activities over a prolonged period of time are, however, needed to reach such a situation. In countries like Germany, the Netherlands and Sweden interest to develop advanced gasification for syngas production is on the rise again and plays a role in long-term RD\&D strategies.

\section{Policy and strategy on bio-energy on European level and example EU countries}

In this section, first some main developments in the policy and strategy of the EC will be discussed, followed by a discussion on some of the frontrunner and active European countries in the bio-energy field. Key drivers, specific national policies, policy instruments deployed and technological choices will be briefly discussed and compared.

\subsection{Europe}

\subsubsection{The European commission}

The EC has been supporting bio-energy since the eighties from various perspectives, evident from various policy paper and targets, directives and research programs. Key bodies involved in bio-energy are the Directorate General-Transport and Energy (DGTREN), responsible in particular for shorter-term demonstration activities and market development and Directorate General-Research and Technology Development (DG-RTD), responsible for the longer-term development of technologies and related research.
The activities of DG-TREN and RTD on energy span a very diverse portfolio of options (including all renewables, energy efficiency, $\mathrm{CO}_{2}$ storage, hydrogen, etc.). Priorities and key focal points changed over time depending on priorities set in the different Framework Programs (at the moment the 6th Framework Program is operational). In the mid- and late eighties, the bulk of the money was spent through the various research and demonstrations programs, including bio-energy technologies and support measures in various ways. The socalled JOULE program (R\&D on a multitude of energy supply options, including biomass combustion, gasification, pyrolysis, digestion, etc.), and THERMIE (aimed at short- and medium-term demonstration activities, including biomass gasification) were most important in terms of expenditures. ALTENER, SAVE and APAS played a lesser role in this respect, but ALTENER had a large priority because of its policy-related actions.

The latest DG-TREN program is called Intelligent Energy Europe, which encapsulates the old SAVE, ALTENER and STEER program (also a.o. covering energy efficiency) and COOPENER, aimed at international cooperation in the energy field. The overall budget for the latter two amounts $200 \mathrm{M} €$ for the period 2003-2006.

The 6th Framework Program of the EC has been launched in 2002. A major characteristic of this FP is that a limited number of fields, including bio-energy, are selected with the intention to create larger consortia around those topics and support them for prolonged periods of time. Competitive and efficient production of hydrogen-rich syngas (particularly aimed for biofuel production) is put prominently on the agenda. First main RD\&D activities (deploying new instruments as Networks of Excellence and long-running Integrated Projects) are expected to start in 2004.

DG Agriculture is involved in bio-energy through the policy targets on rural development, the CAP and related subsidies. The political pressure to reduce the surplus production of agriculture resulted in allowing crops to be grown for energy (non-food in general) purposes on fallow land while farmers can still qualify for the fallow land subsidies.

\subsubsection{The contribution of bio-energy}

In 1999 the estimated contribution of biomass to the EU energy supply, expressed as fuel input, roughly amounted to about 1900 PJ. This equaled about twothirds of the total renewable energy production in the EU (in turn, renewable energy contributes some $6 \%$ of the total primary energy supply of the EU). ${ }^{1}$ For bioenergy the following trends were observed:

\footnotetext{
${ }^{1}$ Figures on biomass-based energy production should be interpreted with some care however, since in practice monitoring is difficult and the various countries apply different definitions for what is in and
} 
- Heat: In 1990, the production of heat from biomass amounted about $1500 \mathrm{PJ}_{\text {th }}$ rising to over $1800 \mathrm{PJ}_{\text {th }}$ in 1999 (an increase of $2 \%$ per year).

- Electricity: Electricity production from biomass amounted $54 \mathrm{PJ}_{\mathrm{e}}$ in 1990 and rose up to $166 \mathrm{PJ}_{\mathrm{e}}$ in 1999 (an increase of $9 \%$ per year) (Commission of the European Communities, 2001a-d).

- Biofuels: The current contribution of biofuels amounts to some $25 \mathrm{PJ}_{\text {fuel }}$, almost negligible in the total bio-energy production. Still, despite the modest role of biofuels in energy terms, the production and use of biofuels rapidly increased over the past 10 years. Bio-diesel production increased from 80 ktonne in 1993 up to 780 ktonne in 2001. Currently, Germany and France produce the bulk, with minor contributions from Italy and Austria. Ethanol production in the EU increased from 48 to up to 216 ktonne in the same period. France, Spain and Sweden are the three key players in this market. In terms of the share in global bio-ethanol production (amounting about 15 million tonnes at present) the EU is a relatively small player compared to Brazil and the US. In bio-diesel production though, the EU is the world leader (van Thuijl et al., 2003).

The so-called Green Paper was adopted by the EC in 1996 and aimed for a doubling of the share of renewables in the EU-15, increasing the use of renewable energy in the EU to $12 \%$ of the primary energy use by 2010. Remarkably, though, no specific targets for bioenergy were taken up.

The so-called White Paper, which was adopted by the EC in 1997, aims for a "Community Strategy and Action plan, Energy for the Future: Renewable Sources of Energy". A direct result from the White Paper is the Campaign for Take-Off, which aims for realization of the targets of the Green Paper. The campaign covered the period 1999-2003. The so-called ALTENER program had an important role to play in this campaign by funding a variety of activities in the EU for implementation and dissemination of Renewable Energy projects and programs in the member states. ${ }^{2}$

The targets from the White Paper include $828 \mathrm{PJ}_{\mathrm{e}}$ bio-electricity in 2010; a 10-fold increase compared to 1995 , and increasing the share of biomass to power generation from renewables to one-third. In 2001, a directive on the promotion of electricity from renewable energy sources was adopted, aimed to

\footnotetext{
(footnote continued)

excluded in bio-energy. The figure mentioned for example includes MSW with the fossil fuel-based fractions such as plastics. Excluding this fraction would lower the figures mentioned (on primary energy input) with roughly $15 \%$ (Harmelinck et al., 2002) depending on the country in question.

${ }^{2}$ The realization of $20,000 \mathrm{MW}_{\text {th }}$ biomass-fired capacity, $1000 \mathrm{MW}_{\text {th }}$ biogas installations (digestion and landfill gas utilization) and a further 5 million tonne of liquid biofuels are mentioned.
}

increase the share of those sources to $22 \%$ of the total power production in 2010 . Consequently, for biomass, a growth rate of some $6-10 \%$ per year is required to meet the target, which was obviously observed until 2000 , but maintaining such a rate is certainly a challenge, given that cheaper biomass resources are increasingly utilized.

In total, the White Paper projects a $5700 \mathrm{PJ}$ contribution for biomass in 2010, tripling the level of 1999.

In addition, in spring 2003, a directive on biofuels was issued with the objective to increase the consumption of biofuels to $2 \%$ of the diesel + gasoline consumption in 2005 and $5.75 \%$ in 2010 (Commission of the European Communities, 2001a-d, 20003). The directive simultaneously provides the opportunity for member states to adjust their national excise duty systems for automotive fuels in favor of biofuels.

To date, six EU member states have or are going to implement tax schemes to support the use of biofuels (Austria, Belgium, Germany, Spain, Italy and Sweden). Within these tax schemes, biofuels are partly exempted from taxes on fossil transport fuel (Thuijl et al., 2003). The production cost figures summarized in Table 3 indicate that in the case of RME, a full tax deduction can imply an indirect subsidy of some $10-20 € / \mathrm{GJ}_{\text {fuel }}$ to make up for the difference in production costs with regular diesel or gasoline. If the targets for the contribution of biofuels in 2010 would be met this implies a contribution of about $700 \mathrm{PJ}_{\text {fuel }}$.

\subsection{Example countries in Europe}

Table 4 gives a brief summary of the main characteristics of bio-energy use and related policies for a selection of eight most active EU countries in this respect. Clearly, Scandinavia as a whole is a leading region in this area, both in terms of the contribution bioenergy makes as in terms of technological developments. Germany, the Netherlands and the UK are countries with considerable ambitions in the bio-energy field, but with the natural 'handicap' that the national biomass resource base is less abundant than in Northern Europe. France and Spain are key examples in Southern Europe.

All EU-15 countries implemented policies for supporting bio-energy. These include the deployment of compensation schemes, tax deduction (in some cases specifically aimed at biofuels), feed-in tariffs, tax incentives, energy tax exemption, bidding schemes, $\mathrm{CO}_{2}$-tax and quota (Harmelinck et al., 2003). Precise targets on the national level differ strongly however and are hard to compare because of differences in definitions and fuels in or excluded (such as MSW and peat). The same is true for the level of (financial) support provided through the various programs and instruments.

The different countries clearly have chosen very different approaches in developing and deploying various bio-energy options. Partly this is caused by the 
Table 4

Global overview of bio-energy use, policy and developments over time in a selection of EU countries (based on various sources as: Kaltschmitt et al., 1998; Thuijl et al., 2003; Harmelinck et al., $2002+$ country reports of PRETIR study)

\begin{tabular}{|c|c|c|c|c|c|}
\hline Country & $\begin{array}{l}\text { Status of bio-energy, main } \\
\text { achievement and goals }\end{array}$ & Main policy instruments deployed & $\begin{array}{l}\text { Biomass supplies; use and } \\
\text { potential }\end{array}$ & Heat and power & Biofuels \\
\hline Austria & $\begin{array}{l}\text { Biomass accounts for } 11 \% \text { of the } \\
\text { national energy supply. Forest } \\
\text { residues are used for (district) } \\
\text { heating, largely in systems of a } \\
\text { relatively small scale. Some of the } \\
\text { policy measures deployed are } \\
\text { province oriented. }\end{array}$ & $\begin{array}{l}\text { Financial support for individual } \\
\text { heating systems and gasifiers. } \\
\text { Subsidies for farmers producing } \\
\text { biomass (as Rape). Tax reduction } \\
\text { biofuels and tax on mineral fuels. }\end{array}$ & $\begin{array}{l}\text { Mainly forest residues and } \\
\text { production of rape for bio-diesel. }\end{array}$ & $\begin{array}{l}\text { Heat production declined the end } \\
\text { of nineties due to declining } \\
\text { number of classic wood boilers. } \\
\text { Wood boilers for domestic } \\
\text { heating still important. About } \\
\text { one-fifth modern concepts. } \\
\text { Bio-electricity steady grower. }\end{array}$ & $\begin{array}{l}\text { Focus on RME production; no } \\
\text { restriction on annual bio-diesel } \\
\text { production. Production should } \\
\text { increase three-fold in } 2010 \\
\text { compared to current levels. }\end{array}$ \\
\hline Denmark & $\begin{array}{l}\text { Running program for utilization } \\
\text { of } 1.2 \text { million tonnes of straw as } \\
\text { well as the utilization of forest } \\
\text { residues. Various concepts for co- } \\
\text { firing biomass in larger scale CHP } \\
\text { plants, district heating and } \\
\text { digestion of biomass residues. }\end{array}$ & $\begin{array}{l}\text { Long-term energy program; } \\
\text { energy crops to contribute from } \\
2005 \text {. Subsidies for bio-energy } \\
\text { projects up to } 50 \% \text { are possible. } \\
\text { Feed-in tariffs guaranteed for } 10 \\
\text { years. }\end{array}$ & $\begin{array}{l}\text { Use of straw and wood residue, } \\
\text { waste and biogas production } \\
\text { (digestion) and a significant role } \\
\text { for energy crops in } 2010 \text { (total } \\
\sim 150 \text { PJ). }\end{array}$ & $\begin{array}{l}1990-2000 \text {, heat production more } \\
\text { or less constant, electricity } \\
\text { production increased } 10 \text {-fold. }\end{array}$ & $\begin{array}{l}\text { No specific policy on biofuels yet, } \\
\text { but interest to comply with new } \\
\text { EU directives. }\end{array}$ \\
\hline Finland & $\begin{array}{l}\text { Obtains } 20 \% \text { of its primary } \\
\text { energy demand from biomass } \\
\text { (one-third being peat). Especially } \\
\text { the pulp and paper industry } \\
\text { makes a large contribution by } \\
\text { efficient residue and black liquor } \\
\text { utilization for energy production. } \\
\text { Strong government support for } \\
\text { biomass; a doubling of the } \\
\text { contribution is possible with } \\
\text { available resources. }\end{array}$ & $\begin{array}{l}\text { Exemption from energy tax. } \\
\text { Financial support for forest } \\
\text { owners for producing forest } \\
\text { residues. Targets for waste to } \\
\text { energy production. }\end{array}$ & $\begin{array}{l}\text { Forest residues, black liquor } \\
\text { (paper industry; two-thirds of the } \\
\text { total) and to a lesser extent peat } \\
\text { play a key role. Further use of } \\
\text { forest residues likely to result in } \\
\text { more expensive supplies in the } \\
\text { future. }\end{array}$ & $\begin{array}{l}\text { In } 2010 \text { over } 1000 \mathrm{MW}_{\mathrm{e}} \text { biomass } \\
\text { electricity generation capacity } \\
\text { should be installed. Heat } \\
\text { production increased about } 60 \% \\
\text { between } 1990 \text { and } 2000 \text {, electricity } \\
\text { some } 70 \% \text {. }\end{array}$ & $\begin{array}{l}\text { No commercial production for } \\
\text { biofuels. Considerably R\&D } \\
\text { activities on pyrolysis (e.g. } \\
\text { Fortum). }\end{array}$ \\
\hline France & $\begin{array}{l}\text { There is no specific bio-energy } \\
\text { policy in France, but the role of } \\
\text { biofuels (ethanol and bio-diesel) } \\
\text { and biomass for heating is } \\
\text { significant: some } 400 \mathrm{PJ} \text { heat, } \\
50 \mathrm{PJ} \text { of fuel and } 10 \mathrm{PJ}_{\mathrm{e}} \text { are } \\
\text { produced. Growth rates have } \\
\text { been very low however over the } \\
\text { past } 10 \text { years. Biomaterials }\end{array}$ & $\begin{array}{l}100 \% \text { tax exemption for bio- } \\
\text { diesel; } 80 \% \text { for bio-ethanol. } \\
\text { Investment subsidies, R\&D. } \\
\text { Feed-in tariffs waste incineration } \\
\text { and landfill gas probably to be } \\
\text { extended to other options. }\end{array}$ & $\begin{array}{l}\text { Mainly focus on available } \\
\text { resources, residues and wastes for } \\
\text { heat production. } \\
\text { Surplus cereal production and } \\
\text { production rape. Specific } \\
\text { attention for increasing the use of } \\
\text { biomaterials. }\end{array}$ & $\begin{array}{l}\text { Major role for domestic heating, } \\
\text { stable market, no real } \\
\text { technological developments. } \\
\text { Smaller contribution for } \\
\text { collective and industrial heating } \\
\text { systems. Modern boiler concepts } \\
\text { for heat production key are } \\
\text { pursued. Furthermore, } \\
\text { considerable biogas utilization. }\end{array}$ & $\begin{array}{l}\text { One of the leading countries with } \\
\text { respect to biofuel use. High fiscal } \\
\text { support; problems arose in recent } \\
\text { years since support did not } \\
\text { conform to EU legislation on } \\
\text { biofuels. Increasing } \\
\text { competitiveness of biofuels } \\
\text { important objective. }\end{array}$ \\
\hline
\end{tabular}

explicitly included in the strategy. Electricity has a low priority.

Biomass contributes about twothirds of the total energy production from renewables (in turn $6 \%$ of the total). 
Renewables contribute some 3\% to the total energy supply. The contribution of biomass is to increase from about $300 \mathrm{PJ}$ (fuel input) to over $800 \mathrm{PJ}$ in 2010. Waste policies relevant due to stringent targets in re-use and prohibition of landfilling.

Targets for biofuels are ambitious about 10.

Netherlands Biomass and waste contribute over $50 \mathrm{PJ}$ in 2000 . Target for 2007 is $85 \mathrm{PJ}$, going up to about $150 \mathrm{PJ}$ in 2020.

In long-term strategy formulation biomass envisaged to play a key role in the energy supply $(600-1000 \mathrm{PJ}$ in 2040).

Spain Contribution of biomass in total to increase from some $160 \mathrm{PJ}$ (about $50 \%$ of total renewable energy) at present to $430 \mathrm{PJ}$ in 2010 (about two-thirds of renewable energy). RES contribute some $6 \%$ in 2000 with targets for 2010 set at $30 \%$.

Sweden Biomass accounts for $17 \%$ of the national energy demand. Use of residues in the pulp and paper industry and district heating (CHP) and the use of wood for space heating are dominant Biomass projected to contribute $40 \%$ to the national energy supply in 2020 .

UK Renewable energy in total contributes about $1 \%$ to the total energy supply of the UK. Biomass accounts for about twothirds of that. Rapid growth in electricity production from biomass and waste is observed over the past decade. Wastes play a major role, but the UK aims for larger scale use of energy crops on a longer term as well.

Subsidies up to $100 \%$ and support for higher fuel costs.

Various R\&D programs and support measures.

Important role for the Ministry of Agriculture.

Feed-in tariffs for various technologies (differentiating between scales and fuels). Tax measures and subsidies for investments.

Waste and residues main resources. Import of biomas current practice for green electricity production. Import a key role to play for meeting longterm targets.

Use of waste and residues, and also major attention for energy

Tax deduction for investments $(10 \%)$ and direct subsidies (up to $30 \%$ ) and discount on interest (up to 5 points) on bio-energy projects.

Reduced rate excise duty.

Taxation and administrative measures, most notably a $\mathrm{CO}_{2}$ tax and energy tax.

Subsidies for CHP facilities. Tax exemption (energy, environmental and fees) for biofuels; no direct subsidies. Bio-energy part of general GHG MSW large part of total curren mitigation policy. Waste policy of supplies. Energy crops (SRCmajor relevance. Innovative bids Willow in particular) seen as for biofuel projects supported. Duty reduction on biofuels. No direct subsidies. Support for farmers growing SRC.

as new options such as sweet sorghum.

Wood fuels (forest residues) dominate the supplies (about $70 \%$ of the total). Wood marke expanded over time with logistics international trade.

SRC-Willow cultivated on some 14,000 ha. Willow in particular) seen
important for longer term.
Waste and residue utilization of key importance. Rapeseed production to bio-diesel. covering the whole country and
About a doubling of bioelectricity production between 1990 and now (total some $19 \mathrm{PJ}_{\mathrm{e}}$ ). Similar rate for heat (now over 200 PJ). Significant technical developments in smaller scale heat and electricity production concepts (e.g. gasification based)

Waste incineration and co-firing in coal-fired power stations play a prominent role. Furthermore, widespread application of

digestion. Electricity production hould increase some six-fold in the coming 10 years.

Electricity production in particular ambitious targets for biogas production and use. Heat production constant.

MSW incineration accounts for bout $50 \%$ of total energy from biomass. Electricity production increased eight-fold between 1990 and 2000 (up to $4500 \mathrm{GW}_{\text {he }}$ )

Heat production doubled to

almost $40 \mathrm{PJ}$.

One of the leading countries, especially on RME. Germany has no restriction on the production rate of bio-diesel. Total production some $10 \mathrm{PJ}$ in 2000.

Bio-electricity not a very fast grower. Heat production steadily asing from $160 \mathrm{PJ}$
Few small RME projects; major interest in developing syngas routes; R\&D in the area of EtOH production from non-sugar and starch feedstocks.

Both RME and ethano production are increased. Some activities on ethanol from lignocellulosic biomass as well. Target for 2010 is $20 \mathrm{PJ}$ of ethanol.

Main focus on bio-ethanol. Sweden is one of the leading countries in the world developin technology for using lignocellulosic biomass fo ethanol production. Also implementation of Flexible Fuel vehicles and fueling stations.

Policy recently formulated Poluding renewable automotive fuels. 
natural conditions (type of resources and crops, climate) and the structure of the energy system, and also by the specific political priorities linked to the agricultural and forestry sectors in those countries. The frontrunner position of Sweden and Finland is to a large extent directly explained by the strong position of the forestry sector and the available (and leading) capabilities of innovations in this area (see also Wesseling, 1999). A key explanatory factor as to why France focuses on biofuels and production of heat is the excess of (nuclear) electricity production capacity, making electricity production an uninteresting alternative. Also for Sweden this argument is important, because support for bioenergy has especially been granted to production of heat (by means of a $\mathrm{CO}_{2}$-tax fossil fuels for heat generation). For Sweden, this situation may change once nuclear power generation capacity will, as targeted, be decreased. Both Germany and France have a key political as well as cultural interests in their agricultural sectors, explaining the high support levels for rapeseed production as well as ethanol production from surplus cereal production. The activities and recent policy and RD\&D initiatives in Spain, the UK and the Netherlands seem to reflect the interest in the longer term (i.e. after 2012 for which the Kyoto targets were formulated) when desired GHG emission reductions will require far more dramatic contributions from all renewables than projected so far.

\section{Concluding remarks: future outlook for bio-energy in Europe and policy implications}

\subsection{Main trends over the past decade in Europe}

Summarizing, bio-energy plays an essential role in the European ambitions to increase the share of renewable and indigenous energy sources. Various EU countries, most notably in Scandinavia, have a leading position in the world in the bio-energy field. The EC-supported development and implementation of bio-energy since the beginning of the eighties, in particular, through various $R \& D$ programs and more recently via directives on renewable electricity and biofuels.

Over the past decade, substantial growth figures of bio-energy in the EU, particularly for the modern energy carriers electricity, and increasingly and biofuels for the transport sector, are observed. Heat production increased by some $2 \%$ per year between 1990 and 2000, bio-electricity increased by some $9 \%$ per year and biofuel production increased about eight-fold (over $20 \%$ growth per year) in the same period. The 1999 contribution of biomass to the EU energy supply was little less than $2000 \mathrm{PJ}$, some two-thirds of the total renewable energy production in the EU or $4 \%$ of the total energy supply.
Considering the biomass supplies, to date bio-energy is largely produced from wastes and residues. Allover Europe (most notably in Scandinavia) biomass markets are developing from purely regional to international markets, with growing international trade of biomass and biomass-derived energy carriers (Faaij et al., 2002; Vesterinen and Alakangas, 2002). Except for rapeseed production (which is heavily subsidized) and the use of (surplus) food crops (cereals) for ethanol production, dedicated (perennial) energy crop production plays a marginal role so far, despite efforts in various countries (in particular Sweden and the UK) and EC-supported research and pilot projects. Energy crop production in the EU is, however, still relatively expensive compared to (available) waste and residues. The supplies of the latter are increasingly used though and energy cropping will be inevitable once demand for bio-energy keeps growing at rates seen over the past decade.

Heat production (small scale for domestic and industrial applications and via CHP) via a variety of combustion techniques currently provides the bulk of energy generation from biomass. Electricity is produced in CHP plants, waste incineration and particularly cocombustion in existing (coal-fired) power stations. In energy terms, the currently small contribution of biofuels is produced from rapeseed and ethanol from (surplus) food crops.

Over time, the scale at which bio-energy is being used has increased considerably. This is true for the conversion capacity of single plants as well as the biomass supplies and supply chains. State-of-the-art CFB combustion techniques applied at larger scales (i.e. over $100 \mathrm{MW}_{\text {th }}$ ) provide a reliable, efficient and, when combined with cheaper feedstocks such as residues, competitive option to produce power and heat.

Technologies that received much attention over the years in RD\&D activities (of the EU as well as various member states) are gasification (for production of electricity, most notably $\mathrm{BIG} / \mathrm{CC}$ technology) and ethanol production from ligno-cellulosic biomass. Both small-scale gasification integrated with engines and $\mathrm{BIG} / \mathrm{CC}$ technology proved to be expensive and several technical issues difficult to resolve (e.g. gas cleaning as well as system integration). In the meantime advanced combustion (most notably CFB technology) and especially co-combustion in existing power plants provided a strong alternative for the market. In the liberalizing energy markets expensive $R \& D$ trajectories needed to bring down costs of $\mathrm{BIG} / \mathrm{CC}$ technology prove hard to pursue and attention for $\mathrm{BIG} / \mathrm{CC}$ technology decreased over the past years. Nevertheless, the technology probably still has a key role to play once bio-energy use grows to projected levels and more expensive biomass feedstocks must be used.

Ethanol production from ligno-cellulosic biomass is not commercially applied yet, but there is a strong drive 
for development from agro-industries that could convert available residues (as straw) to valuable bio-ethanol. Also, ethanol is easy to use in current infrastructure and vehicle fleets. Various countries (i.e. Sweden, UK, Spain, France, Netherlands) as well as the EC give high priority to this route. Although enzymatic hydrolysis, in particular, offers the potential for low cost and efficient ethanol production, it is not sure if and when competitive cost levels will be reached. Other advanced routes, especially gasification for syngas production and subsequent conversion to methanol, DME, FT liquids or hydrogen played a role in the eighties when oil prices were high. Only recently, partly pushed by the EC biofuel directive, attention for those routes is evident again in research programs of the EC and countries like the Netherlands, Sweden and Germany.

What is striking considering the development of bioenergy is that policy measures, targets and choices proved to be of vital importance for the success of its development. Roughly said, the nineties were a decade where much was achieved for bio-energy, but the focus was on in national programs and contexts. The stronger the national policy in terms of support and legal embedding, the more substantial the results were. The Swedish carbon tax and subsequent development of the biomass (including SRC-Willow production) and CHP markets, German financial support for bio-diesel and CHP, the Danish straw utilization program, Austrian CHP program and the Finnish industrial approach on advanced boiler concepts to name a few, paid off and led to strong positions for those respective countries and industries present.

\subsection{Future strategies for bio-energy}

As summarized, ambitions for bio-energy in the EU are high, up to $6000 \mathrm{PJ}$ in 2010 (tripling compared to 1999 levels) and even more beyond 2010. Bio-energy is the single most important renewable energy source for Europe, both in terms of real production of energy as well as in terms of technically and economically feasible potential.

If Europe wants to realize its ambitions with bioenergy for large-scale use in power generation, biofuels for the transport sector and greening of the industry by using renewable feedstocks, the total demand for biomass supplies will soar. Also competition with alternative use of (available) biomass resources could become a problem and limitation, something which is already observed in specific sectors and regions. Considering the (considerable, but) limited potential for residues and wastes, large-scale production using energy crops is needed. Clearly, perennial crops such as SRC Willow, poplar or grasses as Miscanthus are then to play a key role because of their favorable economic and ecological characteristics compared to conventional food crops.

The extension of the EU with a large number of new members in central and eastern Europe does provide new opportunities for biomass in Europe though. Current land use and productivity of agriculture and the expected major transitions for the agricultural sector in central and eastern European countries (CEECs) once the CAP applies, are likely to lead to reform and rationalization in agriculture, thus providing opportunities for alternative crops. On average lower costs for land and labor in CEECs make energy crop production an attractive option (Dornburg et al., 2003).

Considering the diverse portfolio of options available to use and develop bio-energy further, a key question is which options are likely to play a key role in the future. The major contribution bio-energy is envisaged to make to the energy supply of the EU on a longer term implies that its use cannot be limited to (protected) niche markets and improved efficiency and especially costeffectiveness is required. Several bio-energy options (like RME and smaller-scale CHP) are most likely to be too expensive to be supported by direct or indirect financial instruments, once applied on the scale envisaged by various targets. Furthermore, higher net chain efficiencies are needed to utilize limited resources and land effectively.

The combined need for lower costs and higher efficiency and the use of (more expensive) cultivated biomass for production of high value energy carriers, such as electricity and transport fuels (and biomaterials), points toward larger-scale facilities and advanced conversion options. BIG/CC technology, advanced cofiring schemes and biofuel production from syngas and ethanol from ligno-cellulosic biomass have the potential to meet those criteria, as summarized in Section 2. Various countries and the EC are moving toward those options, although the more recent experiences with demonstration of $\mathrm{BIG} / \mathrm{CC}$ technology illustrate that prolonged support for commercialization of such advanced technologies is required.

However, the more recent trend of liberalization of the energy markets decreased direct support from national governments for technology development. The same is true for investments of the energy sector in longer-term options. For bio-energy, this has proven to be a barrier for further developments, because many options are not profitable yet. The need for financial support and certainty over prolonged periods of time suggests that revisiting this trend is desirable.

In policy terms, the intermixed character of bioenergy with many other policy fields, such as agriculture, forestry and waste treatment, make integrated strategies necessary. For example, the increasing demand for biomass will compete with the conventional forestry 
sector as well as food production at the moment energy crops really take off. Intelligent use of biomaterials and cascading materials in order to optimize GHG mitigation impacts may affect waste treatment strategies in various countries. The question as to what infrastructure should be built and what biomass applications are most desirable, profitable and efficient over time is dauntingly complex, given the wide range of technological options for production of heat, power, fuels and biomaterials (e.g. in construction, chemistry). The availability of biomass resources and uncertain development of biomass markets, due to the dependency on agricultural policies and many other factors, make it difficult to formulate concrete strategies for specific options and regions.

The technology developments and the research development, demonstration \& deployment (RDD\&D) trajectories needed to commercialize mentioned advanced conversion options are expensive and complex and it is unlikely they will be developed and commercialized in one country alone. In addition, those technologies are relevant for the global market.

The same is true for biomass production and supply systems and the building of biomass energy markets. Due to the high development costs and the increasing scale of both project and biomass market developments, together with the relevance of those options and technologies for the global arena, supra-national efforts seem the most suited way to proceed.

Furthermore, certificate and emission trading as well as projects realized as under the intended Clean Development Mechanism or as Joint Implementation activity make it more and more difficult to maintain very specific national policies. The recent biofuel directive is another interesting example of a panEuropean target that potentially has important consequences for a European bio-energy market, both for raw materials as well as high-quality transport fuels. On a short term, this may imply that the role of more classic biofuels is extended, but high costs and limited biomass resources may prove a strong driver for developing more advanced, competitive and efficient alternatives further.

Coordination of efforts seems essential to success and this is where the EC can play a key role.

Resulting from the overview and the discussion in this paper following issues seem essential:

- Line out comprehensive RDD\&D trajectories for key areas, most notably advanced power generation technologies (such as BIG/CC) and biofuel options (such as syngas production for hydrogen, FT and methanol and ethanol production from ligno-cellulosic biomass). Such strategies should not only focus on development of technologies but also in particular on the long-term deployment and (re-)building the required infrastructure and markets for those technologies.
- Develop an international biomass market allowing for international trade. Proper standardization and certification procedures are to be developed and implemented on at least EU but preferably on a global level.

- Ensure, in policy terms, that bio-energy is considered an integral part of energy, agriculture and forestry, waste and industrial policy. Such a holistic approach to biomass is much needed, to avoid future conflicting developments and maximize the benefits of bio-energy deployment.

- Involve European agriculture in building bio-energy production capacity. In particular the development and deployment of perennial crops and their potential in CEECs are of key importance for bio-energy in the long run. The CAP of the EU should fully incorporate bio-energy and perennial crops in particular.

- Specific regional (but also bi- or multi-lateral) efforts are needed to deploy biomass production and supply systems adopted for local conditions, e.g., typical for specific agricultural, climatic zones and socio-economic conditions.

- So far, material substitution through biomass (e.g. feedstock for chemical industries and in construction) received limited attention in national and EC policies. It is recommended biomaterials are considered as an integral part of bio-energy strategies, because combined material and energy applications (e.g. by means of cascading) may prove to have economic and efficiency benefits.

\section{Acknowledgements}

Komninos Diamataras (DG-RTD of the European Commission) and Jean Marc Jossart (AEBIOM; European Biomass Association) are sincerely thanked for providing useful comments and pointing out sources of information.

\section{References}

Biewinga, E.E., van der Bijl, G., 1996. Sustainability of energy crops in Europe, a methodology developed an applied. Centre for Agriculture and Environment, CLM 234-1996, Utrecht, February 1996.

Borjesson, P., 1999. Environmental effects of energy crop cultivation in Sweden-I: identification and quantification, and II: economic evaluation. Biomass and Bioenergy 16, 137-170.

Bridgewater, A.V., 1998. The status of fast pyrolysis of biomass in Europe. Proceedings of the 10th European Biomass Conference and Technology Exhibition, Wurzburg, Germany, pp. 268-271.

van den Broek, R., 2000. Sustainability of biomass electricity systems: an assessment of costs, macro-economic and environmental impacts in Nicaragua, Ireland and the Netherlands. Ph.D. Thesis, Department of Science, Technology and Society, Utrecht University, Utrecht, The Netherlands, October 2000 
van den Broek, R., Faaij, A., van Wijk, A., 1996. Biomass combustion for power generation. Biomass and Bioenergy 11 (4), 271-281.

Commission of the European Communities, 1997. White Paper for a community strategy and action plan: energy for the future: renewable sources of energy. COM (97) 599, Brussels, November 1997.

Commission of the European Communities, 2000. Green Paper: towards a European strategy for the security of energy supply. COM (2000) 769, Brussels.

Commission of the European Communities, 2001a. Communication from the Commission to the European Parliament, the Council, the Economic and Social Committee and the Committee of the Regions on alternative fuels for road transportation and on a set of measures to promote the use of biofuels. COM (2001) 547, Brussels, November 2001.

Commission of the European Communities, 2001b. Communication from the Commission to the European Parliament, the Council, the Economic and Social Committee and the Committee of the Regions on alternative fuels for road transportation and on a set of measures to promote the use of biofuels. COM (2001) 547, Brussels, November 2001.

Commission of the European Communities, 2001c. Proposal for a Council Directive amending Directive 92/81/EEC with regard to the possibility of applying a reduced rate of excise duty on certain mineral oils containing biofuels and on biofuels. 2001/0266 (CNS), Brussels, November 2001.

Commission of the European Communities, 2001d. Proposal for a directive of the European Parliament and of the Council on the Promotion of the use of biofuels for transport. 2001/0265 (COD), Brussels, November 2001.

Commission of the European Communities, 2003. Directive 2003/30/ EC of the European Parliament and of the council of May 2003 on the promotion of the use of biofuels or other renewable fuels for transport, Brussels, 17 May 2003.

Consonni, S., Larson, E.D., 1994a. Biomass-gasifier/aeroderivative gas turbine combined cycles, Part A: technologies and performance modelling. Prepared for Cogen Turbo Power '94, The American Society of Mechanical Engineers' 8th Congress and Exposition on Gas Turbines in Cogeneration and Utility, Industrial and Independent Power Generation, Portland, Oregon, 25-27 October 1994.

Consonni, S., Larson, E.D., 1994b. Biomass-gasifier/aeroderivative gas turbine combined cycles, Part B: performance calculations and economic assessment. Prepared for Cogen Turbo Power '94, The American Society of Mechanical Engineers' 8th Congress and Exposition on Gas Turbines in Cogeneration and Utility, Industrial and Independent Power Generation, Portland, Oregon, 25-27 October 1994.

DOE, 1998. US Department of Energy, Office of Utility Technologies, Renewable energy technology characterizations, Washington DC, USA, January 1998.

Dornburg, V., Termeer, G., Faaij, A., 2003. Economic and Energetic Analysis of Bio-Energy Production by Multi-Product Crops-Case Studies for the Netherlands and Poland. Department of Science, Technology and Society-Utrecht University, Utrecht, The Netherlands. Biomass and Bioenergy, submitted for publication.

Elliott, P., Booth, R., 1993. Brazilian biomass power demonstration project. Special Project Brief, Shell, London, September 1993.

Faaij, A., Hamelinck, C., 2002. Long term perspectives for production of fuels from biomass; integrated assessment and RD\&D priorities. Paper prepared for the 12th European Conference on Biomass for Energy, Industry and Climate Protection, Amsterdam, The Netherlands, 17-21 June 2002.

Faaij, A., van Wijk, A., van Doorn, J., Curvers, A., Waldheim, L., Olsson, E., Daey-Ouwens, C., 1997a. Characteristics and avail- ability of biomass waste and residues in the Netherlands for gasification. Biomass and Bioenergy 12 (4), 225-240.

Faaij, A., van Ree, R., Waldheim, L., Olsson, E., Oudhuis, A., van Wijk, A., Daey Ouwens, C., Turkenburg, W., 1997b. Gasification of biomass wastes and residues for electricity production. Biomass and Bioenergy 12 (6).

Faaij, A., Hekkert, M., Worrell, E., van Wijk, A., 1998a. Optimization of the final waste treatment system in the Netherlands. Resources, Conservation and Recycling 22, 47-82.

Faaij, A., Meuleman, B., Van Ree, R., 1998b. Long term perspectives of $\mathrm{BIG} / \mathrm{CC}$ technology, performance and costs. Department of Science, Technology and Society, Utrecht University and The Netherlands Energy Research Foundation (ECN), Report prepared for NOVEM (EWAB 9840), December 1998.

Faaij, A., Schlamadinger, B., Solantausta, Y., Wagener, M., 2002. Large scale international bio-energy trade. Paper prepared for the 12th European Conference on Biomass for Energy, Industry and Climate Protection, Amsterdam, The Netherlands, 17-21 June 2002.

Hall, D.O., Rosillo-Calle, F., Williams, R.H., Woods, J., 1993. Biomass for energy; supply prospects. In: Johansson, T.B., Kelly, H., Reddy, A.K.N., Williams, R.H. (Eds.), Renewable Energy, Source for Fuels and Electricity. Island Press, Washington, DC.

Hamelinck, C.N., Faaij, A., 2002. Future prospects for production of methanol and hydrogen from biomass. Journal of Power Sources 111 (1), 1-22.

Hamelinck, C.N., van Hooijdonk, G., Faaij, A., 2003. Prospects for ethanol from ligno-cellulosic biomass: techno-economic performance as development progresses. Copernicus Institute, Department of Science, Technology and Society, Utrecht University, Report No. NWS-E-2003 55, November 2003, p. 29.

Harmelinck, M., Voogt, M., Joosen, S., de Jager, D., Palmers, G., Shaw, S., Cremer, C., 2002. PRETIR, implementation of renewable energy in the European Union until 2010. Report Executed within the Framework of the ALTENER Programme of the European Commission, DG-TREN. ECOFYS BV, 3E, Fraunhofer-ISI, Utrecht, The Netherlands, $2002+$ various country reports.

Hillring, B., 2002. Rural development and bioenergy-experiences from 20 years of development in Sweden. Biomass and Bioenergy 23 (6), 443-451.

Hoogwijk, M., Faaij, A., van den Broek, R., Berndes, G., Gielen, D., Turkenburg, W., 2003. Exploration of the ranges of the global potential of biomass for energy. Biomass and Bioenergy 25 (2), 119-133.

IIASA/WEC, 1998. Global energy perspectives. In: Nakicenovic, N., Grubler, A., Mc Donald, A. (Eds.), International Institute for Applied Systems Analysis (IIASA) and World Energy Council (WEC). Cambridge University Press, Cambridge.

International Energy Agency, 1994. Biofuels, Energy and Environment Policy Analysis Series. OECD/IEA, Paris.

Ishitani, H., Johansson, T.B., 1996. Energy supply mitigation options. Chapter 19 of the Second Assessment Report; Climate Change 1995, Impacts, Adaptations, and Mitigation of Climate Change: Scientific-Technical Analyses, The Contribution of Working Group II to the Second Assessment Report of the Intergovernmental Panel on Climate Change. Cambridge University Press, Cambridge.

De Jager, D., Faaij, A., Troelstra, W.P., 1998. Cost-effectiveness of transportation fuels from biomass. ECOFYS, Department of Science, Technology and Society, Utrecht University, Innas B.V., Report prepared for NOVEM (EWAB rapport 9830), June 1998.

Kaltschmitt, M., Reinhardt, G.A., Stelzer, T., 1996. LCA of biofuels under different environmental aspects. Institut für Energiewirtschaft und Rationelle Energieanwendung (IER) Universität, Stuttgart. 
Kaltschmitt, M., Rosch, C., Dinkelbach, L. (Eds.), 1998. Biomass Gasification in Europe. Institute of Energy Economics and the Rational Use of Energy (IER), University of Stuttgart. Report prepared for the European Commission, DG XII, EUR 18224, October 1998.

Kwant, K.W., 2003. Renewable energy in the Netherlands: policy and instruments. Biomass and Bioenergy 24 (4-5), 265-267.

van Loo, S., Koppjan, J. (Eds.), 2002, Handbook Biomass Combustion and Co-firing. Twente University Press, Enschede, The Netherlands.

Lynd, L.R., 1996. Overview and evaluation of fuel ethanol from lignocellulosic biomass: technology, economics, the environment and policy. Annual Review of Energy and the Environment 21, 403-465.

Meuleman, B., Faaij, A., 1999. Overview of co-combustion options for coal fired power plants. Report prepared within the Framework of the JOULEIII COBIOCOWA Project Department of Science, Technology and Society, Utrecht University, March 1999.

Naber, J.E., Goudriaan, F., Louter, A.S., 1997. Further development and commercialisation of the small scale hydro-thermal upgrading process for biomass liquefaction. Proceedings of the Third Biomass Conference of the America's. Montreal.

Nikolaisen, L., et al. (Eds.), 1998. Straw for Energy Production. Centre for Biomass Technology, Denmark (available at: http://www.videncenter.dk).

NUTEK, 1996. Energy in Sweden 1995. NUTEK, Stockholm.

Ogden, J.M., Steinbugler, M.M., Kreutz, T.G., 1999. A comparison of hydrogen, methanol and gasoline as fuels for fuel cell vehicles: implications for vehicle design and infrastructure development. Journal of Power Sources 79, 143-168.

Rodrigues, M., Faaij, A., Walter, A., 2003. Techno-economic analysis of co-fired biomass integrated gasification/combined cycle systems with inclusion of economies of scale. Energy, The International Journal 28 (12), 1229-1258.

Serup, H., et al. (Eds.), 1999, Wood for Energy Production. Centre for Biomass Technology, Denmark (available at: http:// wwwvidencenter.dk).

SHELL, 1995. The evolution of the world's energy system 1860-2060, extracts of a study by Shell International. Shell International/Shell Centre, London, December 1995.

Solantausta, Y., Bridgewater, T., Beckman, D., 1996. Electricity Production by Advanced Biomass Power Systems. VTT Technical Research Centre of Finland, Espoo, Finland (Report No. 1729).

Stahl, K., 1997. Varnamo demonstration plant-a demonstration plant for biofuel-fired combined heat and power generation based on pressurized gasification, construction and commissioning
1991-1996. A publication by Sydkraft, Elforsk and NUTEK, July 1997, p. 169

Stassen, H.E., 1995. Small scale biomass gasification for heat and power production: a global review World Bank Technical Paper Number 296, Energy Series, Washington, DC.

TERES, 1997. The European renewable energy study (TERESII). Prepared by ESD for the European Commission, DG XVIIEnergy, published and produced by Merlin Multimedia, Ltd., UK.

van Thuijl, E., Roos, C.J., Beurskens, L.W.M., 2003. An overview of biofuel technologies, markets and policies in Europe. Energy Research Foundation of the Netherlands, Report ECN-C-03-008, Petten, The Netherlands, January 2003, pp. 64

Turkenburg, W.C. (Convening Lead Author), Faaij, A. (Lead Author), et al., 2000. Renewable Energy Technologies. Chapter 7 of the World Energy Assessment of the United Nations, UNDP, UNDESA/WEC. UNDP, New York, September 2000.

Tijmensen, M.J.A., Faaij, A.P.C., Hamelinck, C.N., van Hardeveld, M.R.M., 2002. Exploration of the possibilities for production of Fischer Tropsch liquids via biomass gasification. Biomass and Bioenergy 23 (2), 129-152.

Vesterinen, P., Alakangas, E., 2002. Report on a workshop on biomass trade in Europe, 5 November 2002, Skelleftea, Sweden. Organized by EUBIONET, 28 November 2002.

de Visser, E., 2004. Technological learning in bio-energy systemsbiomass fired CHP systems in Sweden. Copernicus Institute for Sustainable Development, Department of Science, Technology and Society, Utrecht University, February 2004.

Wesseling, M., 1999. Bio-energie vergeleken: kan Nederland leren van het succesvolle buitenland? Department of Science, Technology and Society, Utrecht University, Utrecht, October 1999.

Williams, R.H., Larson, E.D., 1996. Biomass gasifier gas turbine power generating technology. Biomass and Bioenergy 10, 149-166.

Williams, R.H., Larson, E.D., Katofsky, R.E, Chen, J., 1995. Methanol and hydrogen from biomass for transportation, with comparisons to methanol and hydrogen from natural gas and coal. Centre for Energy and Environmental Studies, Princeton University, Report No. 292, July 1995.

WRR (Ed.), 1992. Ground for Choices: Four Perspectives for the Rural Areas in the European Community, Vol. 42. Rapporten aan de regering, WRR (Wetenschappelijke Raad voor het Regeringsbeleid). Sdu uitgeverij, Den Haag.

Wyman, C.E., Bain, R.L., Hinman, N.D., Stevens, D.J., 1993. Ethanol and methanol from cellulosic biomass. In: Johansson, T.B., Kelly, H., Reddy, A.K.N., Williams, R.H. (Eds.), Renewable Energy, Source for Fuels and Electricity. Island Press, Washington, DC. 